\title{
JURISDIÇÃO VOLUNTÁRIA E REGISTRO DE IMÓVEIS
}

\author{
VOLUNTARY JURISDICTION AND PROPERTY REGISTRATION
}

\author{
Carlos Cini Marchionatti ${ }^{\mathrm{I}}$ \\ Adalberto Narciso Hommerding ${ }^{\text {II }}$
}

\footnotetext{
I Universidade do Vale do Itajaí, Itajaí, SC, Brasil. Doutorando em Direito.

E-mail: anhommerding@gmail.com

${ }^{\text {II }}$ Universidade Regional Integrada do Alto Uruguai e das Missóes - URI, Santo Ângelo, RS, BRasil. Doutor em Direito.

E-mail: anhommerding@gmail.com
}

Resumo: Na forma da lei e da Constituição, o Juiz tem o dever fundamental de justificar as decisóes que prolata nos casos que lhe são submetidos. Lei e equidade têm destaque como critérios que justificam o julgamento judicial. Podese também julgar por conveniência ou oportunidade no âmbito da jurisdição voluntária, em que o Juiz não fica condicionado à legalidade estrita que obriga, por exemplo, o Oficial do Registro de Imóveis. O Oficial não pode dispensar as exigências legais previstas ao registro de um título, mas o Juiz pode justificar a dispensa desta ou daquela exigência legal e determinar o registro. Este trabalho destinase à demonstraçấo de como o Juiz pode julgar e ampliar a possibilidade do registro que náo se pode obter diretamente do Oficial. A efetivação do registro no exercício da jurisdição voluntária tem enorme alcance jurídico e resulta em benefício da Sociedade, destinatária da atividade do Poder Judiciário.

Palavras-chave: Conveniência e Oportunidade. Decisão Judicial. Jurisdição Voluntária. Registro de Imóveis.

\begin{abstract}
In the form of law and Constitution, the Judge has the fundamental duty to justify his decisions. Law and equity has deserved prominence as criteria that justify the judicial judgment. One can also judge by convenience or opportunity within the Voluntary Jurisdiction, where the Judge is not conditioned to the strict legality, which obliges the Property Registry Officer. The Official may not waive the legal requirements set forth for a title's Registration, but the Judge can justify the waiver of this or that legal requirement and determine the registration. This work aims to demonstrate how the Judge judges and expands the possibility of the registry, which cannot be obtained directly from the Official. The achievement of the registration by the voluntary jurisdiction has huge legal scope and results in the benefit of the Society, which is the recipient of the Judiciary's activities.
\end{abstract}

Keywords: Convenience and Opportunity. Judicial Decision. Voluntary Jurisdiction. Property Registration. 


\section{Introdução}

O objeto deste artigo é distinguir a relação existente entre a jurisdição voluntária ${ }^{1}$ e o Registro de Imóveis ${ }^{2}$ no sentido de que o Juiz, no exercício da jurisdição voluntária quando aplicada nalgumas questóes envolvendo o Registro de Imóveis, pode adotar em cada caso a solução que reputar mais conveniente ou oportuna, ao passo que o Registrador fica adstrito ao critério da legalidade estrita. Isso não significa, evidentemente, que o Juiz pode afastar-se da Constituição e da lei, mas que esta e os critérios da legalidade estrita, equidade e conveniência e oportunidade, passam a integrar o "princípio constitucional do dever fundamental de justificar as decisóes" ${ }^{3}$ que, por sua vez, deve balizá-los. Dito de outro modo, apesar da utilização de tais critérios, o dever fundamental de justificar as decisões judiciais não deixa - ou não pode deixar - de ser respeitado pelos juízes quando estes decidem no âmbito dos procedimentos afeitos à jurisdição voluntária e ao Registro de Imóveis.

Não se desconhece que algumas críticas ${ }^{4}$ vêm sendo feitas a respeito da possibilidade do uso de tais critérios, uma vez que, resumindo tais objeçóes, constituiriam eles expedientes de "retificação da lei supostamente injusta para a solução do caso concreto suscitado em juízo", despertando o "fantasma de Bülow" e o "voluntarismo judicial". Tais apontamentos, portanto, não passam aqui despercebidos. De fato, fora o desgaste do princípio da legalidade, pilar do Estado Democrático de Direito, o campo de conceituaçáo da equidade, conveniência ou

1 Também chamada de ou conhecida por jurisdição administrativa, jurisdição graciosa, honorária ou nãocontenciosa.

2 O Registro de Imóveis é o cartório onde se registram os direitos reais sobre imóveis ou se averbam situaçôes sobre os imóveis registrados. O conceito é extraído do artigo 1.227 do Código Civil, o bastante aos propósitos deste trabalho e sem descurar de que cada imóvel tem matrícula própria em que se registram atos jurídicos relacionados legalmente e averbam atos acessórios também relacionados legalmente.

3 A designação é amplamente utilizada teórica e judicialmente e, especialmente, embasa-se em texto de STRECK, Lenio Luiz. Hermenêutica e princípios da interpretação constitucional. In: CANOTILHO, J.J. Gomes; SARLET, Ingo Wolfgang; STRECK, Lenio Luiz; MENDES, Gilmar Ferreira. Comentários à Constituição do Brasil. 2. ed. São Paulo: Saraiva Educação, 2018, p. 83 [Série IFP]. O capítulo em referência denominase: "Princípio quatro: o dever fundamental de justificar as decisôes ou de como a motivação não é igual à justificação". Vê-se na página 85: "Há de se levar em conta, ademais, que justificar quer dizer fundamentar. E que isso vai além do "motivar". Posso ter vários motivos para fazer algo; mas talvez nenhum deles seja justificado. Isto quer dizer que fica afastada a possibilidade de se dizer que o juiz primeiro decide para só depois fundamentar (ou "motivar")".

4 Nesse sentido, consulte-se: STRECK, Lenio Luiz; DELFINO, Lúcio. Novo CPC e decisão por equidade: a canibalização do Direito. In: Revista Consultor Jurídico (CONJUR), 29 de dezembro de 2015, 7h49min. Disponível em: https://www.conjur.com.br/2015-dez-29/cpc-decisao-equidade-canabalizacao-direito

5 No seu A Teoria das Exceçóes Processuais e dos Pressupostos Processuais, publicado em 1868, Bülow concebeu o processo como uma relação jurídica pública e contínua, que avança gradualmente e que se desenvolve passo a passo, lastreada primordialmente na figura do juiz (as partes seriam levadas em conta unicamente no aspecto do seu vínculo e cooperação com a atividade judicial). No original: "Se trata en el proceso de la función de los oficiales públicos y desde que, también, a las partes se las toma cuenta únicamente en el aspecto de su vinculación y cooperación con la actividad judicial”. BÜLOW, Oskar Von. La Teoría de las Excepciones Procesales y los presupuestos procesales. Buenos Aires: Ediciones Jurídicas Europa-America, 1964, p. 2. Essa defesa do protagonismo judicial foi tornada explícita depois, na sua obra de 1885, Gesetz und Rechteramt (Lei e Magistratura), no qual defende uma aplicação livre e, em certa medida, subjetiva do direito pelos juízes: uma teoria da criação do direito pelo juiz. Bülow, assim, é um jurista bem identificado com a socialização do processo.Veja-se, nesse aspecto, a crítica a Bülow em: NUNES, Dierle José Coelho. Processo Jurisdicional Democrático: Uma Análise Crítica das Reformas Processuais. Curitiba: Juruá, 2008, p. 98-101. Também em: LEAL, André Cordeiro. Instrumentalidade do Processo em Crise. Belo Horizonte: Mandamentos, Faculdade de Ciências Humanas, FUMEC, 2008. 
oportunidade pode ser bastante amplo, implicando riscos à autonomia do sistema de Direito quando da construção do provimento judicial, já que nele possibilita a entrada de elementos exógenos calcados no subjetivismo particular do Juiz, liberando, assim, o julgador das amarras da lei. Pois bem.

É possível concordar com tais críticas, em parte. Respondê-las, contudo, demandaria escrever outro texto, considerando não ser objeto deste realizar essa "crítica da crítica". Então, deve ficar claro que, aqui, o que se quer é trabalhar dentro daquilo que o sistema legal pátrio autoriza. E aí, quer se queira ou não, há, sim, a possibilidade do uso, pelos juízes, dos critérios elencados e criticados por parte da doutrina; critérios, reprisa-se, que, bem entendidos, não afastam o dever constitucional fundamental de justificar as decisóes judiciais, apesar, é claro, dos inerentes e inexoráveis riscos que disso decorrem. Em síntese, apesar de se reconhecer a procedência da crítica e todos os problemas envolvendo equidade, conveniência e oportunidade como critérios de julgamento, o artigo trabalha com aquilo que o Código de Processo Civil estabelece. E, nesse sentido, necessariamente, devem ser referidos o art. 140, parágrafo único, dispondo que "o juiz não se exime de decidir sob a alegação de lacuna ou obscuridade do ordenamento jurídico" e "só decidirá por equidade nos casos previstos em lei”, e o art. 723, parágrafo único, referindo que "o juiz não é obrigado a observar critério de legalidade estrita, podendo adotar em cada caso a solução que considerar mais conveniente ou oportuna”.

É sabido e consabido que nos processos cíveis em geral, costuma-se dizer, dá-se destaque como critérios de julgamento à lei ou à legalidade estrita - que, no caso, preponderaria -, e à equidade, quando admissível. Existem também, como critérios de julgar, a conveniência e a oportunidade, ainda pouco descobertos nas concepções da doutrina do Direito Processual Civil e pouco relacionados na ação da jurisprudência, especialmente quando são propícios, tais juízos, na jurisdição voluntária e, mais especialmente ainda, distinguidos para o julgamento judicial das situaçôes pendentes de registro de títulos contendo direitos reais sobre bens imóveis que o Oficial do Registro de Imóveis, por algum motivo, não pode registrar.

A doutrina e os julgados no tema da conveniência e da oportunidade situam-se mais no campo do Direito Administrativo, em especial quando tratam do mérito do ato administrativo ou do poder discricionário ${ }^{6}$. Talvez o que lá se utiliza possa ser utilizado, ainda que em parte, no âmbito da jurisdição voluntária e da construção dos provimentos jurisdicionais nas situaçóes envolvendo o Registro de Imóveis, por exemplo. É que, em determinadas situaçóes envolvendo o Registro de Imóveis, pode o juiz julgar conforme seja mais conveniente e oportuno. Em suma, o que se tem, no cotidiano dos Registros e dos fóruns, são situaçôes de ordem prática que, para fins de solução, podem vir a ser aperfeiçoadas. Veja-se que, na praxe cartorária do Registro de Imóveis, uma vez cumpridas as exigências legais, o Oficial registra o título. Ao qualificar o título para Registro, o Oficial submete-se, entâo, ao critério da legalidade estrita. Complementarmente, a Lei prevê a instauração de procedimento que submete o caso do registro do título à consideração

6 Aliás, Celso Antônio Bandeira de Melo já havia assinalado com algo similar sobre a necessidade de mais estudos também sobre o poder discricionário no ato administrativo: “[...] muito já se escreveu sobre o assunto, ainda há espaço para que muito mais se escreva, pois há tópicos importantes que precisam ser visitados ou revisitados" segundo a obra MELLO, Celso Antônio Bandeira. Curso de Direito Administrativo. 2. ed. São Paulo: Melhoramentos, 2007, p. 10. 
do Juiz competente ${ }^{7}$. Nestas ocasiôes, então, é bem mais do que comum que o Juiz repita o raciocínio do Oficial e igualmente verifique se os requisitos da Lei estão sendo observados.

Ao se reproduzir, porém, o mesmo raciocínio entre o Juiz e o Oficial sob o ponto de vista da legalidade, reduzem-se, para o Registrador, as possibilidades ao registro do título apresentado, enquanto que, para o Juiz, ampliam-se as possibilidades da determinaçáo do registro. Precisamente aqui está a situação jurídica tão estimulante quanto relevante e tão pouco concebida em termos da conveniência e da oportunidade no Processo Civil, ainda que - repitase - não passem despercebidas as críticas feitas a tais critérios.

Na jurisdição voluntária, portanto, a lei processual autoriza ao juiz poder julgar conforme for mais conveniente ou oportuno ${ }^{8}$, com o que se ampliam as possibilidades registrais. Ora, isso náo é pouco, porque o registro traz consigo a realizaçáo do direito real de propriedade imobiliária ou de um dos seus desdobramentos, que é garantia e direito constitucional e individual ${ }^{9}$, e faz com que o título registrado se integre ao Sistema do Registro de Imóveis, determinante da autenticidade, eficácia e segurança imprescindíveis aos atos jurídicos que incorporem direitos reais sobre bens imóveis ${ }^{10}$.

Nesse ponto, por exemplo, alguns aportes advindos das temáticas da Governança, sustentabilidade e da Jurisdição podem ser importantes para auxiliar a esclarecer a função da Jurisdição em casos da espécie. É que, como explica Fábio Peixinho Gomes Corrêa, a "coordenação do que é normativo e abstrato, - a técnica processual - com o que é relativamente mais concreto e particular - as disputas a serem resolvidas pelos Juízes - constitui uma forma de governança judicial" ${ }^{11}$. Essa forma de enxergar a atividade jurisdicional, segundo Corrêa ${ }^{12}$, possibilitaria, então, um "avanço estratégico" para superar "disfunçôes do mecanismo judiciário" geradas, a nosso ver, pelo desconhecimento de como pode o Juiz julgar em sede de jurisdição voluntária, por exemplo, assuntos ou questóes de dúvidas no Registro de Imóveis ${ }^{13}$. O Poder Judiciário, portanto, nessa perspectiva, seria também uma instituição de governança em cujas atividades se podem identificar e realizar estratégias jurídicas com a análise de possibilidades hermenêuticas que efetivamente possam contribuir para o desenvolvimento do tema ${ }^{14}$.

7 Resumidamente, isso se pode fazer mediante o procedimento da dúvida registral previsto no artigo 198 da Lei dos Registros Públicos, que o Oficial encaminha ao Juiz mediante requerimento do apresentante do título, ou pela denominada "dúvida inversa", criação da praxe forense, em que o interessado se dirige diretamente ao Juiz.

8 Caso do art. 1.109 do Código de Processo Civil de 1973 e do art. 723, parágrafo único do atual Código de Processo Civil, Lei no 13.105, de 16 de março de 2015.

9 Consoante o que dispóe a Constituição da República Federativa do Brasil em seu artigo 5o, incisos XII e XIII, principalmente.

10 Consulte-se a Lei dos Registros Públicos, nome dado à Lei no 6.015 de 31 de dezembro de 1973, em especial os artigos $1^{\circ}$ e 167 .

11 CORRÊA, Fábio Peixinho Gomes. Governança Judicial. São Paulo: Quartier Latin, 2012, p. 14.

12 CORRÊA, Fábio Peixinho Gomes. Governança Judicial. São Paulo: Quartier Latin, 2012, p. 14-15.

13 O tema Governança permitiria cogitaçóes até mesmo mais abrangentes, porque é ampla com sentido estratégico: "Não se vincula exclusivamente à legalidade e controle. Uma boa governança é aquela que traça um horizonte, define um propósito, alinha as estruturas, desdobra os objetivos e metas e tem um sistema robusto de processos críticos que sustenta suas estratégias, garantindo uma execução e um controle de excelência”: JOHANNPETER, Jorge Gerdau. Prefácio. In: NARDES, João Augusto Ribeiro. Governança Pública. 2. ed. Belo Horizonte: Forum, 2016, p. 21.

14 Em paráfrase à observação feita pelos organizadores na Apresentação da obra BODNAR, João Henrique Pickcius Celant; RUDSON, Marcos (Org.). O Judiciário como instância de governança e sustentabilidade: descobertas, dúvidas e discordâncias. Florianópolis: 2018, p.15. 
Este artigo, a partir dessas consideraçóes, observa, então, duas partes: a) na primeira, distingue-se a existência legal da jurisdição voluntária em meio a qual surge a interação com a matéria do registro de títulos no Registro de Imóveis por decisão judicial; e b) na segunda, trabalha-se com alguns dos critérios que dáo conteúdo ao dever fundamental de justificar a decisão que o Juiz profere, demonstrando-se a real incidência da jurisdição voluntária no Registro de Imóveis.

\section{Jurisdição voluntária, conveniência e oportunidade}

Segundo a doutrina ${ }^{15}$, "Um dos temas árduos do processo civil é a conceituação de jurisdição voluntária e contenciosa”. A controvérsia, assim, "está longe de encerrar-se, e tão imprecisos e flutuantes são os contornos da denominada jurisdição graciosa que um dos processualistas mais eminentes do nosso século admitiu sem rebuços desconhecer-lhe a exata natureza" ${ }^{16}$.

Neste trabalho, a bem da verdade, não cabe a reconstituição da divergência doutrinária do que se entende por jurisdição voluntária e sua diferenciação da jurisdição contenciosa, mesmo que haja divergências doutrinárias no tema que até mesmo se estendem a própria existência da jurisdição voluntária ${ }^{17}$. Dentro dos limites e do plano deste trabalho, como já referido, chama-se a atenção ao reconhecimento da sua existência nos códigos e leis, e sob o ponto de vista de servir às decisôes judiciais. Independente dos caminhos sinuosos da discussão doutrinária imbuída da finalidade de demonstrar uma espécie de "essência jurídica" da jurisdição voluntária, fato é que não há lugar para negar a existência da modalidade jurisdicional, pois está disciplinada legal e juridicamente, e assim se encontra em situação de aplicação judicial na sua plenitude em benefício dos jurisdicionados. Não há, porém, como não deixar de tecer breves consideraçóes acerca da jurisdicionalidade da jurisdição voluntária.

É bem verdade que a doutrina tradicional, em especial a dos maiores responsáveis pela cientificização do processo civil, notadamente os processualistas italianos, não considera a jurisdição voluntária uma verdadeira jurisdição. Tampouco ela é vista como "voluntária”, uma vez que os interessados estariam obrigatoriamente a ela submetidos por imposição da lei. Essa é, por exemplo, a doutrina de Giuseppe Chiovenda, para quem a jurisdição voluntária é uma forma especial de atividade do Estado, exercitada em parte pelos órgãos judiciários, em parte

15 Assim refere Clóvis do Couto Silva, saudoso jurista de renome no Brasil e no exterior, Professor Catedrático de Direito Civil da Faculdade de Direito da Universidade Federal do Rio Grande do Sul, criador do seu Programa de Mestrado em Direito iniciado em 1985 e também Membro da Comissão de Elaboração do Projeto do Código Civil atualmente em vigor desde 11 de janeiro de 2003, nos seus célebres Comentários ao Código de Processo Civil de 1973, obra clássica do Processo Civil brasileiro. SILVA, Clovis do Couto e. Comentários ao Código de Processo Civil. São Paulo: Ed. Revista dos Tribunais, 1977. vol. 11, t.1, p. 4.

16 Assim escreveu Adroaldo Furtado Fabrício nos seus Comentários, também obra clássica, ao mesmo Código processual civil de 1973 ao referir-se à obra de Santiago Sentis Melendo, El Proceso Civil (estudio de la reforma procesal argentina), pág. 360. Adroaldo Furtado Fabrício foi Livre-docente de Direito Judiciário Civil e Professor da Faculdade de Direito da Universidade Federal do Rio Grande do Sul e veio a ser um dos elaboradores do Código de Processo Civil de 2015, do qual foi coordenador o Ministro do Supremo Tribunal Federal Luiz Fux. FABRÍCIO, Adroaldo Furtado. Comentários ao Código de Processo Civil - lei no 5.869, de 11 de janeiro de 1973, vol. VIII, tomo III, arts. 890-945. Rio de Janeiro: Forense, 1984, p. 19.

17 FABRÍCIO, Adroaldo Furtado. Comentários ao Código de Processo Civil - lei no 5.869, de 11 de janeiro de 1973, vol. VIII, tomo III, arts. 890-945. Rio de Janeiro: Forense, 1984, p. 19. 
pelos administrativos, pertencente à "função administrativa"18. Também para Enrico Allorio a jurisdição voluntária seria simples atividade administrativa, mas desempenhada por órgãos que, naturalmente, operam em caráter jurisdicional ${ }^{19}$. Há, porém, posicionamentos em sentido contrário, bastando citar, dentre eles, o de Gian Antonio Micheli, criticado por Allorio, por entender como jurisdicionais os atos de jurisdição voluntária, em que pese a ausência de coisa julgada. Para Micheli, o processo voluntário pertence à jurisdição, e não à administração, embora não tenda à realização do que seja (ou seria) a "finalidade tradicional da jurisdição" ${ }^{20}$, que postula um contraste entre as partes, uma ruptura do equilíbrio entre duas ou mais partes contrapostas, razão pela qual se recorre ao órgão jurisdicional para reconstruir o equilíbrio entre ambas ${ }^{21}$.

Os que defendem, pois, a natureza administrativa da jurisdição voluntária fazem-no por meio dos seguintes argumentos: a) a jurisdição contenciosa é de caráter repressivo, tendo uma função meramente "declaratória" de direitos; a jurisdição voluntária é de caráter preventivo do litígio, tendo função "constitutiva", pois se destina à formação de atos e negócios jurídicos; b) a jurisdição voluntária não possui partes, mas interessados; c) a jurisdição voluntária não

18 CHIOVENDA, Giuseppe. Instituiçôes de direito processual civil. Tradução de J. Guimarães Menegale. v. II. 2. ed. São Paulo: Saraiva, 1965, p. 17. No Brasil, por todos, José Frederico MARQUES, em obra clássica, afirmando que a jurisdição voluntária não pode ser confundida com a jurisdição propriamente dita, pois tem, prevalentemente, caráter administrativo. MARQUES, José Frederico. Ensaio sôbre a jurisdiçấo voluntária. 2. ed. São Paulo: Saraiva, 1959, p. 80.

19 ALLORIO, Enrico. Problemas de derecho procesal. Tomo II. Traduccións de Santiago Santias Melendo. Buenos Aires: Ediciones Jurídicas Europa-América, 1963, p. 58.

20 Veja-se que aqui Micheli ainda está apegado às idéias de "resolução de lides" e "declaração do direito", como características essenciais da jurisdictio.

21 ALLORIO, Enrico. Problemas de derecho procesal. Tomo II. Traducción de Santiago Sentís Melendo. Buenos Aires: Ediciones jurídicas Europa-America, 1963, p. 99. Quanto à natureza da jurisdição voluntária, diz Micheli: "no comparto la tendencia a excluir de la jurisdicción todos aquellos casos en los que, al faltar los elementos típicos, propios de ciertos procesos jurisdiccionales, el proceso mismo es considerado como manifestación del poder administrativo; es la hipótesis de la jurisdicción voluntaria". Mais adiante, prossegue dizendo: "Hasta ahora se han considerado tipos de tutela jurisdiccional, alcanzables a través del proceso civil, de cognición, de ejecución y cautelares; tipos de tutela que presuponen la intervención del juez para restablecer el equilibrio violado o que se teme sea violado. Es éste el contenido típico, tradicional, de la tutela jurisdiccional, pero no es ciertamente el exclusivo, cuando se piensa que la producción de determinados efectos jurídicos pueden subordinarse por el proprio legislador a la intervención del juez civil y a un pronunciamiento suyo. En estos casos, el juez emite, por consiguiente, una providencia que tiene la eficacia de producir una situación jurídica nueva, aun cuando entre los sujetos interesados en dicha providencia no exista controversia alguna. Es la hipótesis, ya recordada, de los procesos de interdicción y de inhabilitación, los cuales, no obstante las formas asumidas de los procesos normales de cognición, no conducen a la concreta actuación de una tutela jurisdiccional a favor de un sujeto contra otro, o contra otros sujetos, sino que realizan objetivamente la tutela de determinados intereses, indicados en cada caso por el legislador, independientemente de la existencia de controversias. La intervención del juez, en estos casos, se considera necesaria por el legislador a fin de someter a un órgano imparcial la declaración de certeza de determinados presupuestos - en general de legitimidad y a veces de fondo - para la producción de un efecto jurídico; declaración de certeza que el legislador no puede llevar a cabo preliminarmente, en el momento de la posición de la norma jurídica y que, por consiguiente, deja efectuar al juez que está autorizado excepcionalmente para esto por ley misma. Tal declaración de certeza puede deferirse, siempre por el legislador, en lugar de al juez, a un órgano administrativo; pero es una cuestión de politica legislativa, la elección de uno o de otro órgano, según que el legislador se preocupe más de salvaguardar un interés público del cual sea portadora de una cierta rama de la administración pública, o bien de dar una tutela idónea a un interés de sujetos singulares, interés considerado general para toda la colectividad de los coasociados (como el interés en la buena administración de los patrimonios de menores o incapaces, de bienes dotales, etc.; en la publicidad relativa a las personas juridicas, etc.). En estos últimos casos, el juez continúa la obra del legislador, cuando este ha querido sustraer la declaración de certeza de determinados presupuestos para la producción de un efecto jurídico, ya sea al sujeto interesado, ya sea al órgano administrativo que podría encontrarse también en contraste con el interés del sujeto a proteger". MICHELI, Gian Antonio. Curso de derecho procesal civil. v. I. Traducción de Santiago Sentís Melendo. Buenos Aires: Ediciones Jurídicas Europa-América, 1970, p. 8, 89-90. 
produz coisa julgada; d) a jurisdição voluntária visa administrar interesses privados, e não à "atuação do direito objetivo". Essas objeções, porém, não têm ficado sem resposta ${ }^{22}$. Primeiro, porque a jurisdição não tem apenas função declaratória. A jurisdição contenciosa também serve para a constituição do direito por meio das demandas constitutivas (aliás, todo ato de aplicação é constituição, construção, num sentido fenomenológico ${ }^{23}$ ). Da mesma forma, a jurisdição voluntária, e não só a contenciosa, tem um caráter de resolução, ou seja, de "prevenção" de litígios ${ }^{24}$. A jurisdição voluntária é verdadeira jurisdição, pois a chamada "atuação" do direito objetivo não se dá apenas no processo contencioso, mas, de igual forma, nos processos sem lide (sempre há applicatio ${ }^{25}$ ! ${ }^{26}$. Quanto à questão da preventividade, há inúmeros casos de atividade contenciosa que não são repressivas, mas preventivas ${ }^{27}$. E quanto ao fato de não existirem "partes" na jurisdição voluntária, deve-se averiguar qual o "conceito" de parte a se adotar: se parte for considerado o elemento de um todo, que é o litígio, aí realmente não há parte na jurisdição voluntária. Por outro lado, se forem entendidos como partes aqueles que participam da relação processual, então é possível afirmar que há partes também na jurisdição voluntária ${ }^{28}$.

A posição acerca da natureza da jurisdição voluntária, especialmente quanto a saber se integra ou não a jurisdição, depende, assim, do conceito que se haja adotado acerca desta última. Consequentemente, se for dado à jurisdição um caráter mais amplo, no sentido de que não inclua somente resolução de conflitos, a jurisdição voluntária certamente a integrará. Ao contrário, se for incluída entre seus elementos a presença da coisa julgada, ficará de fora ${ }^{29}$. A crítica relativa à inexistência de coisa julgada na jurisdição voluntária e de que, em virtude disso, ela não seria verdadeira jurisdição, também é facilmente respondida. Há casos na jurisdição contenciosa em que não há produção de coisa julgada ${ }^{30}$. Como exemplo, pode-se referir o da sentença no antigo processo cautelar do Código de 1973. Ali não há uma "declaração forte" o suficiente para produzir coisa julgada.

22 Por todos, respondendo às críticas: SILVA, Ovídio A. Baptista da. Curso de processo civil: processo de conhecimento. v. 1. 4. ed. rev. e atual. São Paulo: Revista dos Tribunais, 1998, p. 44-49.

23 Nesse sentido, consulte-se: STRECK, Lenio Luiz. Hermenêutica jurídica e(m) crise: uma exploração hermenêutica da construção do direito. 10. ed. rev., atual. e ampl. Porto Alegre: Livraria do Advogado, 2011.

24 SCHÖNKE, Adolfo. Derecho procesal civil. Barcelona: Bosch, 1950, p. 58.

25 Por todos: GADAMER, Hans-Georg. Verdade e método: traços fundamentais de uma hermenêutica filosófica. Tradução de Flávio Paulo Meurer. 3. ed. Petrópolis: Vozes, 1999.

26 DEVIS ECHANDIA, Hernando. Teoria general del proceso: aplicable a toda clase de procesos. Tomo I. Buenos Aires: Editorial Universidad, 1984, p. 85-86. A jurisdiçáo contenciosa, portanto, também constitui novos estados jurídicos, como, por exemplo, numa ação de anulação de casamento, numa ação de separação judicial contenciosa ou numa ação de investigação de paternidade, em que, respectivamente, são constituídos os estados jurídicos de solteiro, separado e de pai. A doutrina tem afirmado que as demandas de investigação de paternidade são declaratórias. Aqui, contudo, sem adentrar na questão se são, ou não, declaratórias, está-se aderindo à idéia de Antunes VARELA, para quem as investigatórias têm eficácia preponderantemente constitutiva. VARELA, Antunes, BEZERRA, J. Miguel, NORA, Sampaio e. Manual de processo civil. 2. ed. rev., e actual. de acordo com o dec-lei 242/85. Coimbra: Coimbra, 1985.

27 Basta que se verifiquem os casos da sentença cautelar, visando preservar o bem, e da ação declaratória pura, tais como as hipóteses das demandas contra o INSS, para reconhecimento de tempo de serviço rural.

28 Nesse sentido, SILVA, Ovídio A. Baptista da. Curso de processo civil: processo de conhecimento. v. 1. 4. ed. rev. e atual. São Paulo: Revista dos Tribunais, 1998, p. 44-49.

29 VÉSCOVI, Enrique. Teoría general del proceso. Bogotá: Temis, 1984, p. 128.

30 Conforme SILVA, Ovídio A. Baptista da. Curso de processo civil: processo de conhecimento. v. 1. 4. ed. rev. e atual. São Paulo: Revista dos Tribunais, 1998, p. 44-49. 
Por fim, o juiz decide na jurisdição voluntária não só para, por exemplo, tutelar interesses de um incapaz, mas para garantir a atuação de um interesse protegido pela lei. O juiz, nos processos de jurisdição voluntária, é táo imparcial quanto o seria se o processo fosse de jurisdição contenciosa. Agirá no interesse do titular apenas se ele tiver razão, como o fará em qualquer processo contencioso ${ }^{31}$. Não há, então, uma "distinção metafísica", dualística, entre o juiz que atua nos casos de jurisdição voluntária e o que atua na jurisdiçáo contenciosa. Leo Rosenberg, aliás, além de considerar errônea a concepção segundo a qual a jurisdição voluntária serve para a criaçáo de direitos, enquanto que a contenciosa para o reconhecimento de um direito existente, lembra que, frequentemente, assuntos relativos ao procedimento de jurisdição voluntária são remetidos à jurisdição contenciosa, e vice-versa ${ }^{32}$. Em todo o caso, como se pode constatar, mesmo as noçôes de "parte", "jurisdicionalidade do ato", "finalidade" da jurisdição, "atuação da lei" etc., todas elas carecem da interpretação, pois não contêm um "significado" a priori, que dela possam prescindir.

$\mathrm{Na}$ síntese, contudo, como explica Pontes de Miranda, $\mathrm{O}$ "autor da ação de jurisdição voluntária exerce a pretensão sem ter que enfrentar a contenciosidade” 33 . Faz, pois, voluntariamente, sem litígio ${ }^{34}$. E, às vezes, como diz Pontes, "é o próprio juiz que dá início à jurisdição voluntária, tal como ocorre com a herança jacente, a arrecadaçáo de bens de ausentes" ${ }^{35}$. E o que se passa, entáo, no Registro de Imóveis? Ora, no Registro de Imóveis, em relação ao título apresentado para registro, o Oficial registra ou exige providências para registrar. Não se conformando o apresentante com a exigência do Oficial, ou não a podendo satisfazer, será o título, a requerimento do apresentante, e com a declaração da dúvida, remetido ao juízo competente para dirimir a dúvida do Oficial a requerimento do apresentante ${ }^{36}$. O requerimento do apresentante é voluntário, típico à jurisdição voluntária; não há litígio do apresentante com o

31 SILVA, Ovídio A. Baptista da. Curso de processo civil: processo de conhecimento. v. 1. 4. ed. rev. e atual. São Paulo: Revista dos Tribunais, 1998, p. 47.

32 ROSENBERG, Leo. Tratado de derecho procesal civil. Tomo I. Traducción de Ângela Romera Vera. Buenos Aires: Ediciones Jurídicas Europa-America, 1955, p. 74-75. Veja-se, por exemplo, o caso de um arrolamento judicial que está em andamento e no qual o juiz venha a constatar que há um menor ou um outro incapaz qualquer que seja herdeiro. Nesse caso, o juiz deve determinar ao inventariante que proceda ao inventário, e não ao arrolamento, uma vez que este serve tão-somente para os casos em que não há herdeiros incapazes. Posição intermediária quanto ao tema adota Leonardo Greco, para quem a jurisdição voluntária é administrativa quando exercida por órgãos da administração pública sem as garantias de independência, impessoalidade e imparcialidade; jurisdicional quando exercida pelos juízes e por quaisquer órgãos judiciais ou extrajudiciais que as exerçam com as referidas garantias, e quase jurisdicional quando exercida por serventuários da justiça sob a direta disciplina e fiscalização dos juízes. GRECO, Leonardo. Jurisdição voluntária moderna. São Paulo: Dialética, 2003, p. 20. Jorge Miranda também sufraga um “ecletismo" quanto à natureza da jurisdição voluntária, dizendo que esta se encontra numa "zona cinzenta" entre a função administrativa e a função jurisdicional, pois consiste em "atos substancialmente administrativos revestidos de forma judicial". MIRANDA, Jorge. Manual de direito constitucional. Tomo V. Actividade constitucional do Estado. 2. ed. Coimbra: Coimbra, 2000, p. 3435.

33 MIRANDA, Pontes de. Comentários ao Código de Processo Civil, tomo XVI: arts. 1.103 a 1.210. Rio de Janeiro: Forense, 1977, p. 3.

34 MIRANDA, Pontes de. Comentários ao Código de Processo Civil, tomo XVI: arts. 1.103 a 1.210. Rio de Janeiro: Forense, 1977, p. 3.

35 MIRANDA, Pontes de. Comentários ao Código de Processo Civil, tomo XVI: arts. 1.103 a 1.210. Rio de Janeiro: Forense, 1977, p. 4-5.

36 Art. 198 da Lei n. 6.015, de 31 de dezembro de 1973. 
Oficial, que não é parte, mas Oficial do Registro de Imóveis; e no procedimento não são devidas custas, salvo as devidas pelo interessado se a dúvida registral imobiliária for julgada procedente ${ }^{37}$.

A Lei dos Registros Públicos (Lei n. 6.015, de 31 de dezembro de 1973), no seu artigo 204, determina, por sua vez, que "A decisão da dúvida tem natureza administrativa e não impede o uso do processo contencioso competente". Está aí, entáo, legalmente expresso, que o procedimento tem natureza administrativa, o que, transposto à jurisdiçáo dentro do processo civil, destaca a incidência da jurisdição voluntária, que resulta multiplicadamente tipificada, assim pela letra especial e expressa da lei como pelo requerimento voluntário do interessado para que o Oficial leve a dúvida ao Juiz, que, então, agirá para evitar o litígio - que, ainda assim, poderá ocorrer -, considerando que seria inconstitucional e ilegal proibir processo contencioso segundo as regras da jurisdição contenciosa, e contrário ao direito constitucional de petição ou ao direito e garantia individual da apreciação pelo Poder Judiciário de lesão ou ameaça a direito ${ }^{38}$.

Assim, embora também não se desconheçam - e com elas até se concorde - as perspectivas que, no paradigma do Estado Democrático de Direito, entendem ser a jurisdição o "instrumento" do processo, e não mais este o instrumento da jurisdiçãa ${ }^{39}$, fato é que a jurisdição continua sendo a atividade do estado dirigida à realização do ordenamento jurídico ${ }^{40}$. As autoridades judiciárias, portanto, podem ser e são encarregadas de funçôes que não têm caráter jurisdicional, funçóes que constituem, como se consagrou na doutrina, "exercício de atividade administrativa", que

37 Art. 207 da Lei n. 6.015, de 31 de dezembro de 1973.

38 Constituição da República, artigo 5º, inciso XXXV.

39 A crítica, por exemplo, de André Cordeiro Leal à concepção de processo como instrumento da jurisdição (que deita raízes na ciência bülowiana, congruente com o socialismo processual e com o Movimento do Direito Livre) faz com que - no limite - se inverta esta lógica, ou seja, que a jurisdição seja compreendida como o instrumento do processo democrático. Explicando melhor, o processualista mineiro, negando o caráter de "ciência" da empreitada de Bülow (que é qualificada como uma tecnologia da jurisdição), nega a existência de uma jurisdição legitimada a priori, ou seja, nega a identidade entre a atividade judicial e a atividade jurisdicional. O processo, então, não seria um "meio" (como em Bülow) para a obtenção de uma decisão vinculativa do poder estatal, que teria como destinatários meros coadjuvantes da relação jurídicoprocessual, mas um procedimento regido pela principiologia constitucional. Sua saída é desenvolver (com inspiração em Fazzalari) uma teoria do processo jurisdicional a partir do processo, seguindo da noção de que todo provimento normativo estatal tem origem no procedimento que o prepara. O entretecimento entre direito e legitimidade, visto a partir de uma compreensão procedimentalista do direito (teoria discursiva da democracia), faz com que se institucionalize o chamado "princípio do discurso" (Habermas) por meio da principiologia constitucional do processo (contraditório, ampla defesa e isonomia). E, assim, não há jurisdição sem que um procedimento assegure as condiçóes para que os afetados pelas decisóes possam participar da construção e interpretação normativas, bem como fiscalizá-las. LEAL, André Cordeiro. Instrumentalidade do Processo em Crise. Belo Horizonte: Mandamentos, Faculdade de Ciências Humanas, FUMEC, 2008, 45-63. Por sua vez, para Fazzalari, o processo é um procedimento que se desenvolve em contraditório. Nas suas palavras, o processo "é um procedimento do qual participam (são habilitados a participar) aqueles em cuja esfera jurídica o ato final é destinado a desenvolver efeitos: em contraditório, e de modo que o autor do ato não possa obliterar as suas atividades"; e o contraditório consiste "na participação dos destinatários dos efeitos do ato final em sua fase preparatória; na simétrica paridade de suas posiçôes; na mútua implicação de suas atividades (destinadas, respectivamente, a promover e impedir a emanação do provimento); na relevância das mesmas para o autor do provimento; de modo que cada contraditor possa exercitar em conjunto - conspícuo ou modesto, náo importa - de escolhas, de reaçóes, de controles, e deva sofrer os controles e as reaçóes dos outros, e que o autor do ato deva prestar contas dos resultados". FAZZALARI, Elio. Instituiçôes de Direito Processual. Campinas: Bookseller, 2006, p. 118-20.

40 CASTRO FILHO, José Olimpio. Comentários ao Código de Processo Civil, v. X: arts. 1.103 a 1.220. 3 ed. Rio de Janeiro: Forense, 1983, p. 4. 
também se distinguem das atividades administrativas comuns, definidas como "administração pública do direito privado" 41 .

No Código de Processo Civil de 1939, os procedimentos de jurisdição voluntária figuravam esparsos entre os denominados de processos especiais, correspondentes ao Livro $I^{42}$. Muito se estranhava, então, a falta de uma jurisdição administrativa ${ }^{43}$. Falar em jurisdição administrativa, no entanto, não significa dizer que a função do estado aí seja administrativa, embora haja funçóes administrativas do Poder Judiciário, como nos demais Poderes. Assim, a jurisdição voluntária ou administrativa não se insere em funçôes administrativas: continua, persiste puramente judiciária. Assim, a tutela que se promete em sede de jurisdição voluntária é puramente judicial, mesmo que o Juiz apenas homologue. $\mathrm{O}$ nome serve para diferenciar de contenciosa que não exclui ${ }^{44}$.

Como explica José Olimpio Castro Filho ao comentar o anterior CPC de 1973, numa de suas "inovaçôes de caráter científico", o "Código Buzaid houve por bem distinguir dentre os procedimentos especiais e reunir num só título os procedimentos especiais de Jurisdição Voluntária” ${ }^{5}$. E, segundo Francesco Carnelutti, entre os tipos funcionais de processo, “[...] o processo voluntário é o que, até agora, tem experimentado menos que os outros em benefício da ciência; naturalmente, devido a que é quase absolutamente ignorada sua função, a sua estrutura vem se formando um tanto caso por caso, sem ordem nem clareza" ${ }^{46}$. Essas perspectivas, até que se prove o contrário, parecem ser verdadeiras entre nós, pois a doutrina e a experiência forense revelam que se dá bem mais atenção à jurisdição contenciosa, enquanto a doutrina processual, em especial, comenta a voluntária sem a ênfase que é conferida àquela, o mesmo ocorrendo com o legislador que parece dificultar sua compreensão e aplicação porque, na passagem entre os códigos processuais de 1973 e 2015, suprimiu do último o art. 1.111 constante do primeiro, segundo o qual "a sentença poderá ser modificada, sem prejuízo dos efeitos produzidos, se ocorrerem circunstâncias supervenientes". Esse dispositivo legal era muito útil e significativo à compreensão - e à tranquilidade - com relação àquilo que se estivesse solucionando judicialmente, cujo objeto nada mais era que a boa administraçáo dos interesses privados ${ }^{47}$ e que poderia ser modulado conforme as circunstâncias supervenientes. A supressão de um tal dispositivo legal abre uma lacuna que trará dúvidas, e, esta, divergência ${ }^{48}$, de modo a reavivar a advertência de

41 CASTRO FILHO, José Olimpio. Comentários ao Código de Processo Civil, v. X: arts. 1.103 a 1.220. 3 ed. Rio de Janeiro: Forense, 1983, p. 6-7.

42 CASTRO FILHO, José Olimpio. Comentários ao Código de Processo Civil, v. X: arts. 1.103 a 1.220. 3 ed. Rio de Janeiro: Forense, 1983, p. 1.

43 MIRANDA, Pontes de. Comentários ao Código de Processo Civil, tomo XVI: arts. 1.103 a 1.210. Rio de Janeiro: Forense, 1977, p. 4.

44 MIRANDA, Pontes de. Comentários ao Código de Processo Civil, tomo XVI: arts. 1.103 a 1.210. Rio de Janeiro: Forense, 1977, p. 4-5.

45 CASTRO FILHO, José Olimpio. Comentários ao Código de Processo Civil, v. X: arts. 1.103 a 1.220. 3 ed. Rio de Janeiro: Forense, 1983, p.1.

46 CARNELUTTI, Francesco. Instituição de processo civil. Trad. Adrián Sotero De Witt Batista. Campinas: Servamda, 1999, p. 281.

47 CASTRO FILHO, José Olimpio. Comentários ao Código de Processo Civil, v. X: arts. 1.103 a 1.220. 3 ed. Rio de Janeiro: Forense, 1983, p. 7.

48 A bem da verdade e de um modo geral, a supressão diz-se proposital, boa ou errônea, feita para caracterizar nos procedimentos de jurisdição voluntária a imutabilidade da coisa julgada, adotando, pois, o código a opinião da doutrina de que a Jurisdição Voluntária é mais jurisdição do que administração. A supressão não evitará a discussão doutrinária e jurisprudencial, como sempre ocorre em situaçôes assim. Caracteriza também um bom 
que a jurisdição voluntária é matéria que entre nós tem sido descurada pela legislação e pela doutrina ${ }^{49}$.

A referência à lei e à conveniência ou à oportunidade ${ }^{50}$ não implica atribuir ao Juiz possibilidade de julgar contra a lei ${ }^{51}$. Os critérios de conveniência ou oportunidade diriam respeito não só ao procedimento, mas, de igual forma, ao direito material ${ }^{52}$. Quem lê o dispositivo legal - e, portanto, o interpreta - encontra, na sua primeira parte, a referência ao prazo da decisão judicial, e, na segunda, a referência de que o Juiz não está obrigado a observar o critério da legalidade estrita, podendo adotar em cada caso a solução que é mais conveniente ou oportuna. O dispositivo legal não distingue se conveniência ou oportunidade referem-se ao procedimento ou à solução. Respeitado, portanto, outro entendimento, os critérios aplicam-se tanto ao procedimento como à solução judicial.

$\mathrm{O}$ recurso às liçôes do Direito Administrativo pode contribuir para o desenvolvimento destas reflexôes, mais familiarizada sua doutrina com o que sejam conveniência e oportunidade. Desde logo se justifica a observação de que o Oficial do Registro de Imóveis, ao registrar, não está obrigado a justificar porque registra, subentendendo-se o cumprimento das exigências legais ao Registro do título apresentado. Quando não registra, portanto, é que incumbe ao Oficial explicitar em nota de devolução ou restituição do título ao apresentante, em que faz o Oficial constar as exigências para registrar ou porque não pode registrar ${ }^{53}$.

episódio para elaborar na perspectiva do tema da Governança, em que as possibilidades de análise e estratégia se potencializam à vista de algumas indagaçóes. A alteração aperfeiçoa ou retrocede? Será pragmática a discussão doutrinária e jurisprudencial? No que se beneficia o jurisdicionado? No Código de Processo Civil de 1939, havia o artigo 288: "Não terá efeito de coisa julgada os despachos meramente interlocutórios e as sentenças proferidas em processos de jurisdição voluntária e graciosa, preventivos e preparatórios e de desquite por mútuo consentimento". A nosso ver, não há dúvidas de que as decisões em Jurisdição Voluntária são retratáveis e recorríveis, não podendo tolher o uso do processo contencioso em Jurisdição Contenciosa, em que se produz a sentença ou o acórdão com a qualidade de coisa julgada, imutável, salvo nulidade ou rescindibilidade, pois, de um modo sintético, a eficácia das decisóes judiciais abrange a (ir)retratabilidade, a (ir)recorribilidade e a coisa julgada. Seja como for, é assunto para estudo em outra ocasiáo.

49 Veja-se, por todos, a monografia considerada por muitos a mais pormenorizada na doutrina brasileira sobre o tema restrito "A Administração Pública e a Ordem Jurídica Privada [Jurisdição Voluntária]". Foi escrita pelo Desembargador Aposentado do Tribunal de Justiça de Minas Gerais e Professor de Direito Processual Civil da Faculdade de Mineira de Direito da Universidade Católica. Editora Bernardo Alvares S.A., Belo Horizonte, 1961, p. 1. A afirmação foi feita na vigência do Código de Processo Civil de 1939 em que inexistia lei especial e, no código processual civil, os procedimentos de jurisdição voluntária estavam envoltos em outros de Jurisdição Contenciosa. Passados tantos anos, é atual. Ultimamente, tem-se atribuído aos Tabeliáes e aos Oficiais de Registro de Imóveis o que se incumbia aos Juízes em Jurisdição Voluntária, de que são exemplos a partilha da herança e o divórcio por escritura pública como o usucapião de imóvel em procedimento extrajudicial no Registro de Imóveis, também tema para melhor ocasião.

50 Feita no art. 1.109 do Código de Processo Civil de 1973, e repetida no parágrafo único do art. 732 do atual de 2015, no sentido de que o Juiz não está adstrito ao critério da legalidade estrita e pode adotar em cada caso a solução que reputar mais conveniente ou oportuna.

51 MIRANDA, Pontes de. Comentários ao Código de Processo Civil, tomo XVI: arts. 1.103 a 1.210. Rio de Janeiro: Forense, 1977, p. 25.

52 MIRANDA, Pontes de. Comentários ao Código de Processo Civil, tomo XVI: arts. 1.103 a 1.210. Rio de Janeiro: Forense, 1977, p. 25. Pontes de Miranda, aqui, parece ter razão, na medida em que a referência à conveniência e à oportunidade refere-se tanto ao procedimento quanto à solução ou decisão.

53 Art. 198 da Lei dos Registros Públicos, Lei n. 6.015, de 31 de dezembro de 1973. 
Nos atos ${ }^{54}$ administrativos públicos distinguem-se os vinculados dos discricionários ${ }^{55}$. Há, assim, discricionariedade ou vinculação. Para a doutrina tradicional ${ }^{56}$, os atos vinculados ou regrados, as normas legais ou regulamentares, estabelecem os requisitos e condiçóes da sua realização, cuja prática fica adstrita aos pressupostos estabelecidos na norma legal para sua validade, que absorvem quase toda a liberdade do administrador, mas sem transformar em cego ou automático executor da prática do ato. Nos atos discricionários ou no poder discricionário, por sua vez, pratica-se com liberdade de escolha de seu conteúdo, seu destinatário, sua conveniência, sua oportunidade e do modo da sua realização. Discrição, então, é a liberdade de ação dentro dos limites legais; assim, o ato discricionário é permitido pelo direito, é legal e válido. Seria, pois, conceito diferente de arbítrio, correspondente à ação contrária à lei ou excedente da lei.

$\mathrm{O}$ ato discricionário, portanto, é legal como o ato vinculado e resulta da faculdade discricionária do Poder Público, pois o administrador terá de decidir se convém praticá-lo em qual ocasião oportuna e atendendo às circunstâncias que conduzam a atividade administrativa ao seu fim, o bem comum ${ }^{57}$. A fonte da discricionariedade, assim - e agora consoante a doutrina contemporânea $^{58}$-, é a lei nos espaços indicados pela lei, porque especial e expressamente prevê, ou quando não consegue fazê-lo por ser impossível prever todas as situaçóes, e quando prevê a competência sem indicar a conduta a ser adotada.

A identidade dessas noções com a temática que aqui se está a discutir fica visível: a lei, que é a Lei dos Registros Públicos, prevê a remessa do título não registrado pelo Oficial ao Juiz, a requerimento do interessado, quando este náo se conforma ou não pode atender às exigências ao Registro. Tal procedimento tem caráter administrativo, aliando-se novamente à Lei, que agora é o Código de Processo Civil, autorizando, assim, o Juiz a adotar a solução que considerar mais conveniente ou oportuna referente ao registro ou ao seu indeferimento, considerando as exigências ou justificando a superaçáo delas, conforme o dever fundamental de justificar as decisóes judiciais e segundo o qual se busca e demonstra o bem comum expresso preponderantemente no registro e em condiçôes de modulação por circunstâncias supervenientes, resguardado eventual processo contencioso.

Aqui, cabe breve menção a um dos sentidos que pode tomar a palavra "discricionariedade", e isso tanto do ponto de vista administrativo quanto do judicial. É Ronald Dworkin, na perspectiva dos Direitos norte-americano e inglês, e em suas críticas ao positivismo jurídico de Herbert Hart, que trabalha com as noçôes de discricionariedade "fraca" e "forte". Dworkin identifica no positivismo jurídico três características nucleares: a) o Direito de uma comunidade é um conjunto de regras especiais utilizado direta ou indiretamente pela comunidade com o propósito de determinar qual comportamento será punido ou coagido pelo poder público. Essas regras especiais podem ser identificadas e distinguidas com auxílio de critérios específicos, de

54 Está consagrado dizer ato administrativo vinculado ou discricionário, com a ressalva de que a discricionariedade não é do ato, é poder discricionário da administração. Aqui a doutrina clássica de MEIRELLES, Hely Lopes. Direito administrativo brasileiro. 39. ed. São Paulo: Malheiros, 2011, p. 173.

55 MEIRELLES, Hely Lopes. Direito administrativo brasileiro. 39. ed. São Paulo: Malheiros, 2011, p. 172.

56 Por todos, MEIRELLES, Hely Lopes. Direito administrativo brasileiro. 39. ed. São Paulo: Malheiros, 2011, p. 172.

57 MEIRELLES, Hely Lopes. Direito administrativo brasileiro. 39. ed. São Paulo: Malheiros, 2011, p. 172-174.

58 DI PIETRO, Maria Sylvia Zanella. Direito Administrativo. 30 ed. rev., atual. e ampl. Rio de Janeiro: Forense, 2017, p. 254. 
testes que náo têm a ver com o seu conteúdo, mas com seu pedigree ou maneira pela qual foram adotadas ou formuladas; b) o conjunto dessas regras jurídicas é coextensivo com "o direito", de modo que se o caso de alguma pessoa não estiver coberto por uma regra dessas (porque não existe nenhuma que pareça apropriada ou porque as que parecem apropriadas são vagas ou por alguma outra razão), então esse caso não pode ser decidido mediante a "aplicação do direito". Ele deve ser decidido por alguma autoridade pública, como um juiz, "exercendo seu discernimento pessoal”, o que significa ir além do direito na busca por algum outro tipo de padrão; e c) dizer que alguém tem uma "obrigação jurídica" é dizer que seu caso se enquadra em alguma regra jurídica válida que exige que ele faça ou se abstenha de fazer alguma coisa ${ }^{59}$.

Dworkin, também explica que o conceito de poder discricionário "só está perfeitamente à vontade em apenas um tipo de contexto: quando alguém é em geral encarregado de tomar decisôes de acordo com padróes estabelecidos por uma determinada autoridade" ${ }^{\prime 0}$. Assim, após sugerir dois sentidos fracos para a plurívoca expressão (ora equiparada à mera exigência de alguma capacidade de raciocinio do tomador de decisão, ora entendida como a potencialidade de dar a última palavra sobre algum assunto), Dworkin finalmente traça um sentido forte de poder discricionário, então compreendido como a ausência de limitaçóes, ao seu titular, de quaisquer padróes (standards) estabelecidos por outra autoridade. Nas suas próprias palavras,

às vezes usamos "poder discricionário" não para dizer que um funcionário público deve usar seu discernimento na aplicação dos padrōes estabelecidos para ele pela autoridade ou para afirmar que ninguém irá rever aquele exercício de juízo, mas para dizer que, em certos assuntos, ele não está limitado pelos padrôes da autoridade em questão. ${ }^{61}$

Essa perspectiva, embora sujeita a discussóes e críticas, ainda é pouco explorada na doutrina brasileira no que diz com as temáticas da discricionariedade judicial ${ }^{62}$, legislativa ${ }^{63} \mathrm{e}$ administrativa, e com relação à jurisdição voluntária; pode, contudo, ser mais bem aproveitada quando se estiver discutindo tais noçôes. A caracterização da jurisdição voluntária é completa, afetada ao poder discricionário do Juiz - que, a bem da verdade, não é e não pode ser discricionário no sentido "forte" apontado por Dworkin, já que vinculado o julgador à lei e à Constituição -, conferido pela lei justamente para superação das dificuldades de ordem prática ao registro no Registro de Imóveis de caso em caso, cujas dificuldades são impossíveis de previsão antecipada. O conhecimento e a experiência permitem afirmar que existirão dificuldades ao registro, mas é impossível dizer quais ou em que estarão calcadas.

59 DWORKIN, Ronald. Levando os Direitos a Sério. Sáo Paulo: Martins Fontes, 2002, p. 27-8.

60 DWORKIN, Ronald. Levando os Direitos a Sério. São Paulo: Martins Fontes, 2002, p. 50.

61 DWORKIN, Ronald. Levando os Direitos a Sério. São Paulo: Martins Fontes, 2002, p. 52.

62 Sobre esse ponto, recomendam-se duas obras essenciais: STRECK, Lenio Luiz. Verdade e consenso: Constituiçãa, hermenêutica e teorias discursivas. Rio de Janeiro: Lumen Juris, 2006; e MOTTA, Francisco José Borges. Levando o direito a sério: uma crítica hermenêutica ao protagonismo judicial. 2. ed. rev. e ampl. Porto Alegre: Livraria do Advogado, 2012. Streck é um dos responsáveis, no Brasil, pela tematização da crítica feita por Dworkin à discricionariedade judicial. Motta é um dos alunos de Lenio e, possivelmente, um dos juristas da nova geração que mais conhecem a obra de Dworkin.

63 Toma-se a liberdade de fazer referência aqui ao livro de um dos autores deste texto: HOMMERDING, Adalberto Narciso. Teoría de la legislación y Derecho como integridad. Curitiba: Juruá, 2012. Na referida obra tematiza-se a discricionariedade legislativa a partir da obra de Ronald Dworkin. Para o autor, também o legislador não tem liberdade absoluta de conformação. 
A razoabilidade e a proporcionalidade - dados os limites do texto, aqui náo se quer adentrar nas discussôes teóricas entre as teorias da argumentação ${ }^{64}$ e a Hermenêutica ${ }^{65}$ a respeito do que deve ser entendido por razoabilidade e proporcionalidade - podem auxiliar a preencher ou descaracterizar o ato discricionário ${ }^{66}$, quando se deixam de indicar os motivos de fato e de direito do ato, aqui da sentença ou decisão, quando deixe de considerar fatos existentes ou públicos e notórios, ou quando não guarde proporção adequada entre meios e fins que a lei deseja alcançar, uma medida desproporcional ou excessiva ao fim, aqui, ao registro do título no Registro de Imóveis.

Ao fim e ao cabo, reunindo algumas dessas consideraçóes, aí estão alguns dos elementos do conceito da discricionariedade administrativa como "competência administrativa" ${ }^{67}$ de avaliar e escolher, em concreto, de fato ou na prática, a melhor solução ao registro, mediante justificativa ${ }^{68}$ válida, que vem a ser os fatos e fundamentos jurídicos da decisão judicial segundo

64 Algumas obras que trabalham essa questão do ponto de vista da teoria da argumentaçáo são as seguintes: ALEXY, Robert. Teoría de la argumentación jurídica. Madrid: Centro de Estudios Políticos y Constitucionales, 1997; ALEXY, Robert. Teoría de los derechos fundamentales. Madrid: Centro de Estudios Políticos y Constitucionales, 1997; ALEXY, Robert. Theorie der juristischen argumentation. Frankfurt: Surkamp, 1978. ATIENZA, Manuel. As razões do direito: teorias da argumentação jurídica. Traducción de Maria Cristina Guimarães Cupertino. São Paulo: Landy, 2000; ATIENZA, Manuel. El derecho como argumentación. Barcelona: Ariel, 2010; ATIENZA, Manuel. Interpretación constitucional. Bogotá: Universidad Libre; Facultad de Derecho, 2010; ATIENZA, Manuel; LOZADA PRADO, Alí. Cómo analizar una argumentación jurídica. Quito: Cevallos, 2009; ATIENZA, Manuel; RUIZ MANERO, Juan. 100 preguntas sobre conceptos básicos del derecho. Alicante: Club Universitario, 1996; ATIENZA, Manuel; RUIZ MANERO, Juan. Las piezas del derecho: teoría de los enunciados jurídicos. 4. ed. Barcelona: Ariel, 2007. No Brasil, para ficar apenas com um desses teóricos: ÁVILA, Humberto. Teoria dos princípios: da definição à aplicação. São Paulo: Malheiros, 2005.

65 Do ponto de vista da Hermenêutica, para esse debate, recomendam-se: STRECK, Lenio Luiz. Hermenêutica jurídica e $(\mathrm{m})$ crise: uma exploraçáo hermenêutica da construção do direito. 10. ed. rev., atual. e ampl. Porto Alegre: Livraria do Advogado, 2011; STRECK, Lenio Luiz. Verdade e consenso: constituição, hermenêutica e teorias discursivas. 4. ed. São Paulo: Saraiva, 2011; STRECK, Lenio Luiz. Jurisdição constitucional e decisão jurídica. 3. ed. reformulada da obra Jurisdição constitucional e hermenêutica. São Paulo: Revista dos Tribunais, 2013. Na Espanha, são adeptos da concepção hermenêutica: OSUNA FERNÁNDEZ-LARGO, Antonio. Hermenéutica jurídica: en torno a la hermenéutica jurídica de Hans-Georg Gadamer. Valladolid: Secretariado de Publicaciones, Universidad, D. L., 1992; SERNA, Pedro. Hermenéutica y relativismo. Una aproximación desde el pensamiento de Arthur Kaufmann. In: SERNA, Pedro (dir.). De la argumentación jurídica a la hermenéutica: revisión crítica de algunas teorías contemporáneas. Segunda edición aumentada. Granada: Comares, 2005.

66 Exemplo dado por Di Pietro, na obra já citada, referindo-se à Constituiçâo do Estado de São Paulo que, no seu art. 111, inclui o princípio da razoabilidade a que se sujeita a administração pública. DI PIETRO, Maria Sylvia Zanella. Direito Administrativo. 30. ed. rev., atual. e ampl. Rio de Janeiro: Forense, 2017.

67 FREITAS, Juarez. Direito Fundamental à Boa Administraçáo Pública. 3. ed. São Paulo: Malheiros Editores Ltda. 2014, p. 24.

68 Pode-se acrescer, aqui, que fundamentar, justificar, explicitar e demonstrar a compreensão judicial e o julgamento que está sendo feito conforme o caso, seus fatos, circunstâncias e provas, tecnicamente é diferente de motivar, mesmo que se igualem na praxe corrente doutrinária e jurisprudencial. O cuidado que se deve ter, então, é o de distinguir que se pode associar o que sejam motivos à intençáo íntima da parte ao declarar sua vontade, típicos à esfera pessoal da elaboração interna, o que é situação jurídica antiga, havendo, inclusive, subsídios a respeito disso no Direito Romano, conforme o que se encontra no "Código Civil dos Estados Unidos do Brasil, comentado por Clovis Beviláqua. Nesse sentido, BEVILÁQUA, Clovis. Código Civil dos Estados Unidos do Brasil. Rio de Janeiro: Ed. Rio, 1958, p. 338. Essa situação está consolidada entre nós desde o monumental Código Civil de 1916, cujo artigo 90 foi repetido e aperfeiçoado no artigo 140 do atual: "O falso motivo só vicia a declaração da vontade quando expresso como razão determinante". O motivo é uma situaçáo íntima, que interessa ao agente. Para se compreender pelo mínimo ou necessário, ao adquirir um imóvel com a expectativa da sua valorização, mas que vem a desvalorizar, este falso motivo ou causa não pode revogar nem anular a declaração da vontade, salvo quando expresso como razão determinante em cláusula contratual. Na Teoria 
a Constituição da República e as leis do país, coerentes e consistentes de sustentabilidade, conveniência ou oportunidade (com razóes juridicamente aceitáveis), "respeitados os requisitos formais e substanciais da efetividade do direito fundamental à boa administração pública" ${ }^{69}$.

Outro ponto que deve ser levado em consideração é que não se pode querer articular institutos do Direito Administrativo em torno da ideia de "poder", pois o correto seria articulálos em torno da ideia de "dever", de finalidade a ser cumprida. Nesse aspecto, a praxe aperfeiçoarse-ia se Juízes e Oficiais pensassem e agissem tendo em mente a ideia de dever antes da de poder, o que permitiria superar com mais prontidão as dificuldades que surgem naturalmente.

Assim também, e mais uma vez reunindo as considerações precedentes, demonstrase perfeitamente jurídico que a mesma decisão judicial seja composta por fundamentos de legalidade estrita e de conveniência ou oportunidade porque não são critérios antagônicos, mas, sim, apenas critérios diferentes, ambos destinados ao encontro da melhor solução, em que um não exclui necessariamente o outro e em que ambos podem justificar a incidência recíproca. Dos julgados em nossos tribunais podem-se colher exemplos dessa conjugação de critérios que levam a uma decisão judicial apta a implementar direitos fundamentais como o direito à propriedade imobiliária. É o caso da decisão monocrática no 70083360164 , da 20a Câmara Cível do Tribunal de Justiça do Estado do Rio Grande do Sul, assim ementada ${ }^{70}$ :

Apelação cível. Dúvida no Registro de Imóveis. Averbaçẫo de construção civil com certidão negativa de débito - CND - em nome da sociedade empresária construtora ou empreiteira no lugar do proprietário da obra. Obra financiada com recursos do Fundo de Garantia do Tempo de Serviço - FGTS dentro do Programa Minha Casa Minha Vida - PMCMV do Sistema Financeira da Habitação - SFH.

O proprietário da obra, que vem a ser o devedor fiduciante no financiamento destinado à aquisição do terreno e à construção da moradia, que apresenta certidáo negativa de débito - CND em nome da sociedade empresária construtora da obra mediante contrato de empreitada, certidão que individualiza a obra residencial feita com financiamento de recursos oficiais e certifica a inexistência de dívida fiscal para a finalidade da precípua da averbação da casa, tem direito à averbação da construção civil como manifestação do direito e da garantia constitucional individual fundamental da propriedade privada imobiliária e como demonstração da regularidade fiscal.

Estes fundamentos principais caracterizam e determinam a improcedência da dúvida que corresponde à objeçấo da averbação da casa como construção civil na matrícula que individualiza o imóvel.

Apelação provida em decisão monocrática do Relator.

Geral do Direito Civil, são muitas as consequências legais, doutrinárias, jurisprudenciais, que aqui não vêm ao caso. Transposto ao raciocínio judicial, é incompatível que o Juiz, por exemplo, julgue por causas ou motivos recônditos, ou, relacionando com o disposto na lei processual civil, por motivos de foro íntimo que levarão ao seu impedimento ou suspeição.

69 FREITAS, Juarez. Direito Fundamental à Boa Administração Pública. 3. ed. São Paulo: Malheiros Editores Ltda. 2014, p. 24.

$70 \mathrm{Na}$ matrícula do Registro de Imóveis, consoante a decisão monocrática procedeu-se, então, ao registro e à averbação da casa construída no terreno. 


\section{A lei, a equidade, a conveniência e a oportunidade como fundamentos possíveis das decisóes judiciais em sede de jurisdiçáo voluntária e Registro de Imóveis}

Não é despiciendo repetir - ainda que possam "chover" críticas sobre o perigo de se acatar tais noçôes como fundamento para decidir - que, no processo civil comum, cujo objeto são os interesses privados, prepondera a aplicação da lei segundo regula a própria lei, âmbito em que o julgamento por equidade corresponderia à exceção à regra. Aí, por exemplo, ao menos do ponto de vista legislativo, distinguir-se-ia, então, o processo especial dos Juizados Especiais Cíveis (Lei no 9.099, de 26 de setembro de 1995) - um dos maiores exemplos de expressão da cidadania e instrumento de progresso (ao menos deveria ser) à realizaçáo da Justiça, e que permitiu chegar ao Poder Judiciário várias lesôes a direitos que dele ficavam fora dado seu valor econômico irrisório - do processo comum. No processo especial civil, que é também contencioso, consoante o art. 5० da Lei no 9.099/95, “o juiz dirigirá o processo com liberdade para determinar as provas a serem produzidas, para apreciá-las e para dar especial valor às regras de experiência comum ou técnica”, e, segundo o art. $6^{\circ}$ do mesmo estatuto legal, o "juiz adotará em cada caso a decisão que reputar mais justa e equânime, atendendo aos fins sociais da lei e às exigências do bem comum”. Invertese, entáo, o raciocínio anterior, porque, na lei que regula o processo civil especial, predomina o julgamento por equidade, mesmo que, na praxe, julgue-se mais pela lei do que por equidade.

Numa ótica legalista, portanto, na medida dos fundamentos possíveis das decisóes judiciais relacionados à jurisdição contenciosa e voluntária, podem ser sistematizadas três categorias: o julgamento conforme a lei, o julgamento por equidade, e o julgamento por aplicação dos princípios da conveniência e da oportunidade. Há pontos comuns e distintivos que, então, se podem desdobrar em novas análises situadas dentro dos mesmos limites da lei, da equidade, da conveniência e da oportunidade. Variadas leis mencionam como podem ou devem ser fundamentadas as decisóes judiciais, com o que se vê que todos os critérios, uma fez filtrados pela Constituição da República, enquanto fundamento, unem-se na legislação como critérios legais de julgamento e se distinguem, assim, como critérios específicos.

Tais distinçóes contam com clássica e consolidada doutrina e ação jurisprudencial. O que pouco ou quase nada se explorou corresponde aos critérios da conveniência e oportunidade atinentes à jurisdição voluntária e projetados no Registro de Imóveis onde se registram a propriedade privada imóvel e os seus desdobramentos, especialmente por ocasiáo do registro do título apresentado e objetado pelo Oficial do Registro de Imóveis.

Mesmo repetindo, a possibilidade de incidência dos critérios não significa julgar contra a lei ou fora da lei, em desrespeito à lei. Significa, sim, julgar conforme a lei e dentro lei, superando uma ou outra exigência que se justifique dispensar. A possibilidade de incidência dos critérios abre uma "porta" para o Juiz analisar adequadamente os fatos e as suas circunstâncias, e concluir pelo que convém e é oportuno dentro dos limites da lei e prestigiando a lei. No fundo, é uma questão de interpretação, sem que se desgarre da constitucionalidade e da legalidade. E daí, então, é possível compreender a natureza da jurisdiçáo voluntária como verdadeira atividade jurisdicional, uma vez que o juiz, por força de uma "ficção necessariamente útil" ${ }^{11}$, que legitima o procedimento

71 A dogmática não teria como se desenvolver se o juiz não fosse visto como um terceiro "neutro" diante das partes. Nesse sentido, toda a dogmática é marcada por uma concepção de direito ligada à atividade jurisdicional, compondo, delineando e circunscrevendo procedimentos que conduzem a autoridade à tomada de decisão. 
(Luhmann), sempre é imparcial, sendo essa "imparcialidade" a nota essencial da jurisdição (Micheli, Ovídio, entre outros), seja ela contenciosa ou voluntária. Aqui, faz-se necessário breve pausa para tratar de outro tema importante no que diz com o processo e o provimento ou decisão judicial: a imparcialidade do julgador. A imparcialidade é um dos princípios básicos do processo $^{72}$. A imparcialidade é um "elemento estrutural" da própria função jurisdicional, que sem ela não seria concebida ${ }^{73}$. O caráter de "terceiro imparcial", portanto, é "fundamental" 74 para a caracterização da jurisdição. Assim, não há como prescindir da imparcialidade do juiz. $\mathrm{O}$ juiz deve ser imparcial no sentido de não ter "interesse pessoal" na solução do litígio, o que não implica sua neutralidade. A imparcialidade - vista sob a ótica de uma visão sistêmica (Luhmann), por exemplo - funcionaria, então, como uma espécie de "mecanismo procedimental" que, embora não imunize totalmente o indivíduo de suas preferências, ao menos resguarda e "alivia" sua carga pessoal e emotiva. O juiz, assim, tem a característica da imparcialidade previamente fixada e socialmente difundida, o que lhe permite manter a devida distância de seus "papeis" não-judiciais, como pai, amigo, colega etc. O sistema de boas relaçôes, assim, é neutralizado sem que o juiz se veja prejudicado em sua vida particular e tenha que se justificar por não ter ajudado, por exemplo, o amigo de seu filho em um processo qualquer. Como último recurso, o sistema faculta-lhe a possibilidade de se declarar impedido. Além disso, o procedimento legitima-se na medida em que os conflitos da vida real não sejam interiorizados pelo sistema, sem perder seu caráter de conflito. Significa dizer que o procedimento só acolhe determinados conflitos sob a condição de estarem previamente fadados a uma solução dentro do sistema de Direito, mesmo que tal solução não seja "real", isto é, mesmo que não resolva de fato o conflito. Por isso é que, se alguém perde uma demanda, pode continuar pensando que foi lesado, mas não pode mais reclamar, uma vez que a decisão, por esse prisma, foi legítima, pois ambas as partes submetem-se às regras do sistema de Direito ${ }^{75}$.

O juiz, evidentemente, não é "desinteressado", pois, afinal de contas, o ser-no-mundo não é um sujeito puro ou desinteressado ${ }^{76}$. Assim, nunca há uma "compreensão pura". Sempre se dá uma compreensão ligada às condições e ao modo de ser-no-mundo ${ }^{77}$. Significa dizer que o existir é fático, mundano. A facticidade é o nosso existir próprio em cada ocasiāo ${ }^{78}$. Está

FERRAZ JR., Tércio Sampaio. Função social da dogmática jurídica. São Paulo: Max Limonad, 1998, p. 83-84. Mas essa "neutralidade" não tem nada a ver com a "imparcialidade" que, para Ferraz Jr., seria a mesma coisa. Esta, a imparcialidade, deve ser vista como uma "não-tendência" do juiz em beneficiar um ou outro litigante.

72 Nesse sentido, por todos: ARAGONESES ALONSO, Pedro. Proceso y derecho procesal: introducción. Madrid: Aguilar, 1960, p. 89.

73 VÉSCOVI, Enrique. Elementos para uma teoría general del proceso civil latinoamericano. México: UNAM, 1978, p. 25.

74 Por todos, na doutrina estrangeira, VÉSCOVI, Enrique. Teoría general del proceso. Bogotá: Temis, 1984, p. 118.

75 LUHMANN, Niklas. Legitimação pelo procedimento. Tradução de Maria da Conceição Corte-Real. Brasília: Universidade de Brasília, 1980.

76 Nenhum juiz pode ser psicologicamente imparcial (neutro) de modo absoluto: sua razão sempre está afetada, em maior ou menor proporção, por sua formação cultural, pelo meio familiar, social e econômico de onde provém e vive; pelas suas concepçóes religiosas, pela sua vida universitária, necessidades, virtudes e vícios, prejuízos, complexos, traumas, fobias e mecanismos de defesa, temperamento e atitudes. SAGÜES, Néstor Pedro. $L a$ interpretación judicial de la Constitución. Buenos Aires: Depalma, 1998, p. 6. Não sendo neutro, mas devendo ser imparcial, não pode o juiz admitir que os princípios constitucionais se tornem parte de um "discurso retórico-ornamental”. Deve buscar efetivá-los, tornando-os "law in action”. Nesse sentido, AZEVEDO, Plauto Faraco. Aplicação do direito e contexto social. 2. ed. São Paulo: Revista dos Tribunais, 2000, p. 158.

77 STEIN, Ernildo. Aproximaçôes sobre hermenêutica. Porto Alegre: Edipucrs, 1996, p. 61.

78 HEIDEGGER, Martin. Ontología: hermenéutica de la facticidad. Versión de Jaime Aspiunza. Madrid: Alianza 
na questão do núcleo do processo hermenêutico o fato de que não há um sujeito puro. Há um sujeito concretamente definido e historicamente situado ${ }^{79}$. A interpretação judicial é uma interpretação que deve ser "imparcial", pois se diferencia das "interpretaçóes interessadas", que podem ser feitas pelos advogados em favor de seus clientes ou por dirigentes políticos em prol de seus partidos. A "gestão" interpretativa do juiz, portanto, haverá de ser desinteressada. É essa nota de "imparcialidade" ou de "desinteresse" na interpretação judicial da Constituição que significa que o juiz não deve estar a serviço das partes de um processo, senão dos princípios da Constituição. De nenhum modo, porém, é uma hermenêutica "ideologicamente neutra”, pois a Constituição não é neutra. A Constituição tem um "teto" ideológico: as regras constitucionais beneficiam alguns e prejudicam outros, discriminação que é legítima enquanto conduza ao bem comum, e ilegítima quando ocorre o contrário. Assim, é natural que o juiz tenha de efetivar essas diretrizes protetoras ou sancionadoras, salvo hipóteses que lesionem os direitos humanos básicos. Em resumo, não há imparcialidade judicial frente aos princípios da Constituição. Daí por que o juiz que pretender ditar sua sentença prescindindo dessas valoraçôes estará, pois, ditando uma sentença francamente inconstitucional ${ }^{80}$.

A doutrina de grande nome vincula o procedimento de dúvida registral à jurisdição voluntária $^{81}$. O que a própria Lei dos Registros Públicos considera ${ }^{82}$, e da qual se constitui uma das situaçóes mais relevantes, é o fato de que o julgamento da dúvida registral não impede o uso do processo contencioso. Caracterizada a essência administrativa ou da vinculação à jurisdição voluntária, é preciso examinar, então, quais os critérios do julgamento judicial que se podem enfatizar na conveniência e da oportunidade, e na pesquisa e preenchimento dos seus conteúdos. De um modo geral, a doutrina sobre o processo de dúvida no âmbito da Lei dos Registros Públicos costuma tratar das características do procedimento em si, e não especificamente dos critérios predominantes à jurisdição voluntária que estão no Código de Processo Civil. Concomitantemente, a doutrina que comenta a jurisdição voluntária no âmbito do Processo Civil trata principalmente dos procedimentos especiais de jurisdição voluntária relacionados no Código de Processo Civil e da dificuldade ou da polêmica na caracterização da jurisdição voluntária ${ }^{83}$, e das características gerais entre as quais se insere a noção do que possa

Editorial, 1998, p. 41.

79 Sobre a temática, consultar: VATTIMO, Gianni. Introdução a Heidegger. 10. ed. Lisboa: Piaget, 1996, p. 43. A hermenêutica é a janela aberta sobre a história do homem enquanto possibilita a compreensão do passado, da tradição, em que mergulham as raízes do homem e de onde ele pode libertar suas possibilidades. A hermenêutica, assim, é decisiva para o conhecimento da história. Ela situa o homem em sua verdadeira atitude diante da história. Impedirá que o homem ingenuamente se julgue imune e livre das cargas de seu passado, ou que se julgue absolutamente determinado pela tradição. Porém, descerrará também o caminho que permite ao homem apreciar sua verdadeira posição na história, impedindo que sonhe com uma absoluta independência entre teoria e vida. A tentação do espectador imparcial na história não é nada mais que uma tendência para o objetivismo típico das ciências naturais. Nosso conhecimento do passado sempre vem carregado pelas condiçóes que no presente nos ocupam e limitam. O passado que atingimos vem envolto nos problemas, preconceitos e interesses que nos atarefam no presente. STEIN, Ernildo. História e ideologia. 3. ed. Porto Alegre: Movimento, 1972, p. 29.

80 SAGÜES, Néstor Pedro. La interpretación judicial de la Constitución. Buenos Aires: Depalma, 1998, p. 4-5.

81 Entre muitos, ASSIS, Araken de. O procedimento de dúvida e o princípio da adstrição do juiz ao pedido da parte, Revista Jurídica, Ano XXXI, v. 107, p. 35-42, Setembro /Outubro,1984: Para Araken, "o procedimento de dúvida é de modo inequívoco de jurisdição voluntária".

82 Art. 204: "A decisão da dúvida tem natureza administrativa e não impede o uso do processo contencioso competente".

83 Por todos, THEODORO JÚNIOR, Humberto. Curso de Direito Processual Civil. 52. ed. Rio de Janeiro: 
ser o conteúdo dos critérios da conveniência e da oportunidade ${ }^{84}$. Há, porém, escassez de obras jurídicas na caracterização dos critérios e acerca da sua incidência no julgamento da dúvida, assim como são escassos os julgados no âmbito da ação da jurisprudência ${ }^{85}$.

Compreensivelmente, tendo em vista que planejados no âmbito dos respectivos estudos, a doutrina sobre o processo e acerca do procedimento de dúvida, e a doutrina processual civil náo colocam as matérias em interação, apesar do fato de se entrosarem intimamente, podendo, uma vez reunidas e interligadas, promover a possibilidade de ampliação do registro dos títulos registráveis no Registro de Imóveis. De outra maneira, não há o registro em detrimento do próprio sistema do Registro de Imóveis. Então, pensa-se, a doutrina e a ação da jurisprudência podem evoluir segundo a importância da interligação do procedimento de dúvida julgado conforme os critérios da conveniência e da oportunidade, em harmonia como o critério da legalidade estrita.

Ao examinar ou qualificar para registrar, o Oficial do Registro pode registrá-lo mediante a observaçáo dos requisitos da lei; pode também negar ou, como ocorre com muita frequência, pode fazer exigências que, atendidas, levem a efeito, então, o registro. Havendo exigências a serem satisfeitas, o Oficial deve indicá-las por escrito, o que também significa que o Oficial do Registro de Imóveis, cujo serviço se exerce por delegação do Poder Público ${ }^{86}$, deve motivar a exigência segundo a qual se negue ou postergue o registro, que é obrigatório ${ }^{87}$. Não se conformando com

Forense: 2018. II v., p. 473: “A designação ‘jurisdição voluntária’ tem sido criticada porque seria contraditória, uma vez que a jurisdição compreende justamente a função pública de compor litígios, o que, na verdade, só ocorre nos procedimentos contenciosos".

84 Exemplificativamente: GRECO, Leonardo. Jurisdição voluntária moderna. São Paulo: Dialética, 2003, p. 56: "Existem, sem dúvida, na jurisdição voluntária, procedimentos que se destinam a um provimento discricionário, fundado em juízo de conveniência e oportunidade, o que, de nenhum modo significa desobediência ao princípio da legalidade. $\mathrm{O}$ poder discricionário do juiz de escolher uma entre várias soluçóes agasalhadas pela lei não faculta ao juiz violar a lei, não havendo qualquer incompatibilidade entre o critério da legalidade e o exercício do poder discricionário. É o que ocorre, por exemplo, na interdição em que o juiz escolhe este ou aquele irmão do interditando para exercer a curatela”. Além disso, TESHEINER, José Maria Rosa. Jurisdição voluntária. Rio de Janeiro: Aide Ed., 1992, p. 51: "[...] o abandono do critério da legalidade estrita só se pode verificar quando não fira direitos subjetivos dos interessados. Em consequência, a conclusão a que se chega é que o abrandamento da legalidade estrita só é autorizado nos casos de se permitir ou de se determinar prática, sem a formalidade que não lhe seja da essência, ou melhor dizendo, que não se integre na substância do ato. Como exemplo, podemos citar a possibilidade de dispensa de venda em hasta pública de bens pertencentes a incapazes tutelados ou curatelados. Outro exemplo, a nomeação de tutor ou curador, sem obedecer à gradaçáo estabelecida em lei”.

85 Conforme ANDRIGHI, Ministra Nancy. Recurso Especial: resp. 623047 RJ 2004/0010077-2 Inteiro Teor. Julgado em 14 de dezembro de 2004. Superior Tribunal de Justiça STJ. Disponível em: <https://stj.jusbrasil. com.br/jurisprudencia/7233289/recurso-especial-resp-623047-rj-2004-0010077-2/inteiro-teor-12987193>. Acesso em: 17 dez. 2018. Em consonância com a jurisprudência anterior e posterior, conforme os Códigos de Processo Civil de 1973 e 2015, destaca-se da ementa do acórdão: "O art. 1.109 do CPC abre a possibilidade de não se obrigar o juiz, nos procedimentos de jurisdição voluntária, à observância do critério de legalidade estrita, abertura, esta, contudo, limitada ao ato de decidir, por exemplo, com base na equidade e na adoção da solução mais conveniente e oportuna à situação concreta. Isso não quer dizer que a liberdade ofertada pela lei processual se aplique à prática de atos procedimentais, máxime quando se tratar daquele que representa o direito de defesa do interditando".

86 Consoante o art. 236 da Constituição da República Federativa do Brasil, "Os serviços notariais e de registro são exercidos em caráter privado, por delegação do Poder Público".

87 O art. 169 da Lei n. 6.015, de 31 de dezembro de 1973, assim dispóe: "Todos os atos enumerados no art. 167 são obrigatórios e efetuar-se-ão no cartório da situação do imóvel...”. E o art. 172 da mesma lei determina: “No Registro de Imóveis serão feitos, nos termos desta Lei, o registro e a averbação dos títulos ou atos constitutivos, declaratórios, translativos e extintivos de direitos reais sobre imóveis reconhecidos em lei, inter vivos ou mortis causa, quer para sua constituição, transferência e extinção, quer para sua validade em relação a terceiros, que 
as exigências feitas ou não as podendo satisfazer ${ }^{88}$, a requerimento do apresentante será o título remetido ao Juiz mediante a declaração de dúvida. Ao julgar a dúvida, o Juiz pode considerá-la procedente e, então, se restituirão os documentos ao apresentante sem efetivação do registro ${ }^{89}$, ou pode julgá-la improcedente, por efeito do que se procederá ao registro do título ${ }^{90}$.

$\mathrm{Na}$ superaçáo das exigências feitas, o Juiz, segundo a autorização legal, pode, pois, julgar segundo os critérios da conveniência e da oportunidade e autorizar o registro. Na praxe, os Juízes costumam raciocinar com base no critério da legalidade estrita e, assim, repetem o raciocínio do Oficial. Segundo os critérios da conveniência e da oportunidade, no entanto, no âmbito da jurisdição voluntária, desdobram-se ao Juiz maiores possibilidades que não são autorizadas ao Oficial. Simples assim.

Daí a necessidade de diferenciar os critérios que distinguem as atividades do Oficial e do Juiz, propiciando melhor visualização da sistemática registral, aperfeiçoando a possibilidade do registro em benefício do titular do direito e da sociedade, e justificando o registro mediante autorização judicial quando o Oficial não possa fazê-lo.

São inumeráveis os casos que resultam sem registro. Na medida em que o Oficial objeta o registro e o Juiz deixa de autorizá-lo quando pode fazê-lo pela incidência dos critérios da jurisdição voluntária, resultam prejudicados a disposição e o exercício do direito de propriedade ou de um dos seus desdobramentos, correspondentes a todas as modalidades de direitos reais ou obrigacionais desdobrados do direito real de propriedade ${ }^{91}$.

A praxe forense, assim, ainda não dimensionou a enorme possibilidade e a grandeza resultante da aplicação dos dispositivos legais em estudo, centrais e fundamentais à solução de milhares de situaçóes que, de outra maneira, remanescem sem solução ou, por exemplo, dependem de uma sentença predominantemente declaratória de usucapião com fundamento nas características da posse. Justifica-se, aqui, exemplificar com a realidade: havia e há milhares de incorporações imobiliárias que resultaram em condomínios edilícios sem registro no Registro de Imóveis. As causas podem variar e variam muito. A variedade distingue os fatos e as circunstâncias de caso em caso, superando em muito as previsóes da lei, que teria de conter e propiciar a solução possível. Muitos fatores dificultam ou impossibilitam registrar: do desaparecimento ou da quebra da sociedade empresária construtora ou incorporadora à dificuldade ou impossibilidade de obter os documentos e plantas que a lei enumera para propiciar o registro. O edifício existe, as pessoas nele residem, trabalham e vivem; negociam entre si as respectivas unidades edilícias mediante instrumentos particulares ou simples recibos de mão em mão, destituídos da autenticidade, da fidelidade e da segurança de uma escritura pública e do registro na matrícula, propiciando, então, ocupaçóes e litígios, intranquilidade ou aflição. A usucapião, com fundamento na posse, é admissível teoricamente, mas na prática não resolve tudo. O Oficial do Registro não pode e tampouco tem como efetivar o registro porque não se dispóe dos documentos exigíveis pela

para a sua disponibilidade.

88 Os artigos 198, caput, e 1.496, ambos do Código de Processo Civil, Lei no 13.105, de 16 de março de 2015, dispóem sobre as normas fundamentais e da aplicação das normas processuais.

89 Art. 203, inciso I, da Lei dos Registros Públicos.

90 Art. 203, inciso II, da Lei dos Registros Públicos.

91 No art. 1.225 do Código Civil são elencados os direitos reais. A Lei dos Registros Públicos, no artigo 167, relaciona os títulos objeto de registro (inciso I e respectivas letras) e de averbação (inciso II e respectivas letras). Leis especiais também criam direitos reais e regulam o registro, entre as quais se destacam a Lei de Incorporaçóes Imobiliárias e a Lei de Parcelamento do Solo Urbano. 
lei. O Juiz, porém, avaliando o que seja mais conveniente e oportuno, diante do fato e das suas circunstâncias, conforme se justifique, pode autorizar o registro dispensando este ou aquele documento, medida que beneficiará a todos os condôminos, titulares das unidades edilícias, e aperfeiçoará o Registro de Imóveis, completando-o com o que antes não dispunha. Em consequência, beneficiará a sociedade como um todo, promovendo o exercício pleno da propriedade privada como expressão do direito constitucional individual da propriedade $\operatorname{privada}^{92}$.

A jurisdição voluntária tem características que oferecem segurança à decisão Judicial, apesar de o juiz poder valer-se de critérios de conveniência e oportunidade. A sentença podia ser modificada se ocorrerem circunstâncias supervenientes. No atual Código de Processo Civil, como já referido, não se repetiu o artigo 1.111 do Código de 1973: "A sentença pode ser modificada, sem prejuízo dos efeitos já produzidos, se ocorrerem circunstâncias supervenientes”. É o que se caracteriza como coisa julgada formal típica à jurisdição voluntária. A modificação podia ser produzida nos mesmos autos, seja por requerimento de interessado, seja por informação do Oficial do Registro ou mesmo por provocação do Ministério Público. A supressão do artigo em referência, assim, não parece adequada à praxe judicial, mas não pode evitar novo pedido por razōes distintas ${ }^{93}$.

$\mathrm{Na}$ cidade de Porto Alegre houve situação incomum, hoje local dos mais aprazíveis e belo, desde quando se aterrou onde hoje se situam o Hipódromo do Cristal, o Barra Shopping Sul, o Hipermercado Big, dois clubes náuticos e um campo de futebol afeto ao Grêmio Football Porto-Alegrense, além do calçadão para passeio e recente marina para o transporte fluvial e pública por meio do Catamarã entre as cidades de Porto Alegre e Guaíba. A primeira descrição ou individualização do aterramento registrado foi errônea, do que decorreu a primeira retificação mediante autorização judicial. Anos depois, verificou-se também errônea essa primeira retificação, quando, entáo, passou pela segunda retificação judicial, que também anos depois ainda foi havida como incorreta. Promoveu-se, então, a terceira retificação judicial ${ }^{94}$. Fosse no âmbito da

92 Foi o caso da sentença prolatada nos autos do processo 01191420759 da Vara dos Registros Públicos da Comarca de Porto Alegre, proferida em 3 de dezembro de 1998, segundo a qual, pela primeira vez na vara competente, autorizou-se a regularização registral de um condomínio edilício iniciado em 1950, na vigência da lei antiga e não mais em vigor, que fora substituída pela Lei no 4.591, de 16 de dezembro de 1964, dispondo sobre o condomínio em edificações e incorporação imobiliária, cuja construção foi concluída pelos condôminos depois da falência da incorporadora, composto de 50 apartamentos, 3 lojas, subsolo e dependências de uso comum. A decisão judicial segundo os critérios justificou o registro que de outro modo não se propiciava. Entre os fundamentos da sentença salienta-se: “[...] sendo aconselhável que se estabeleça o condomínio de edifício, em benefício de todos os condôminos, [...] cujos direitos ficam inteiramente ressalvados..." e "[...] não se infringe a nenhum princípio basilar do sistema do registro de imóveis, ao contrário [...] a medida judicial propicia que se regularize a situação registral do edifício, de acordo com a sua realidade e vontade dos condôminos".

93 A questão é propícia para desenvolvimento em outro estudo, porque o atual dá mais ênfase aos critérios em si.

94 Em síntese, feito o aterro de grandes proporçôes, procederam-se às alienaçóes e verificou-se descrição insuficiente e inferior à realidade, daí as retificações sucessivas mediante autorização judicial. A terceira retificação se operou por meio de requerimento do Município de Porto Alegre em processo próprio junto à Vara dos Registros Públicos, consistente em averbar a individualização da área remanescente para abertura de matrícula, situação que as duas retificaçóes judiciais anteriores não propiciavam. A sentença proferida em 15 de junho de 1998. Entre os fundamentos da sentença: "[...] efetivando-se a retificação em sua descrição, posteriormente, constatouse equívoco em seu procedimento, ordenando-se, em consequência, o seu cancelamento”. Entấo, a terceira retificação fez-se assim em razão do remanescente: “[...] necessita também vir a ser averbado junto ao registro imobiliário, e não se logrará fazê-lo a não ser com autorização judicial, sendo sua descrição absolutamente diversa da área original, embora pertencente a ela ou oriunda dela”. O artigo 212 da Lei n. 6.015, de 31 de 
jurisdição contenciosa, tais medidas não seriam possíveis ou se dificultariam por efeito da coisa julgada material, que torna imutável a decisão judicial.

O registro no Registro de Imóveis, preponderantemente, diz com títulos registráveis que tenham por objeto bens imóveis. A concepção da função socioambiental, por exemplo, redimensiona a noçáo da propriedade e pode influenciar no registro em benefício da sociedade. Assim, é que o registro de um título que tenha por objeto direito real de bem imóvel adequado às normas socioambientais há de ser considerado diferentemente do registro que tenha por objeto bem imóvel localizado em uma área de risco à vida humana ou à natureza. E daí se podem distinguir as providências judiciais, seja pela definiçấo do registro, seja pela adoção de medidas que protejam o meio ambiente, a requerimento do Ministério Público como Curador dos Registros Públicos ou de ofício pelo Juiz de Direito ou pelo Tribunal de Justiça. Os critérios processuais da conveniência e da oportunidade, portanto, podem gerar um pragmatismo benéfico à sociedade.

\section{Consideraçóes finais}

A aplicação dos critérios da conveniência e da oportunidade, típicos à jurisdição voluntária, não foram suficientemente dimensionados na praxe forense no julgamento das dúvidas registrais imobiliárias. O Oficial do Registro de Imóveis, ao qualificar o título apresentado para Registro, está submetido à legalidade estrita. O Juiz de Direito, ao julgar a dúvida registral imobiliária, pode julgar ou adotar a soluçáo que reputar mais conveniente ou oportuna, o que amplia as possibilidades do registro, que não se conseguiria sem solução judicial. Justificadamente, sem descurar do dever fundamental de fundamentação das decisóes, o Juiz pode dispensar esta ou aquela exigência ao Registro. O benefício é de todos: do interessado, do Sistema do Registro de Imóveis e da comunidade em geral, diante da autenticidade, da publicidade e da segurança advindos do registro.

\section{Referências}

ALLORIO, Enrico. Problemas de derecho procesal. Tomo II. Traduccións de Santiago Santias Melendo. Buenos Aires: Ediciones Jurídicas Europa-América, 1963.

ANDRIGHI, Ministra Nancy. Recurso Especial: resp. 623047 RJ 2004/0010077-2 Inteiro Teor. Julgado em 14 de dezembro de 2004. Superior Tribunal de Justiça STJ. Disponível em: <https://stj.jusbrasil.com.br/jurisprudencia/7233289/recurso-especial-resp-623047rj-2004-0010077-2/inteiro-teor-12987193>. Acesso em: 17 dez. 2018.

ARAGONESES ALONSO, Pedro. Proceso y derecho procesal: introducción. Madrid: Aguilar, 1960.

ASSIS, Araken de. O procedimento de dúvida e o princípio da adstrição do juiz ao pedido da parte, Revista Jurídica, Ano XXXI, v. 107, p. 35-42, Setembro /Outubro, 1984.

dezembro de 1973, prevê a retificação por meio de procedimento administrativo ou judicial. No art. 216 da mesma lei encontra-se o processo contencioso. 
AZEVEDO, Plauto Faraco de. Aplicação do Direito e contexto social. São Paulo: Editora Revista dos Tribunais, 1996.

AZEVEDO, Plauto Faraco. Aplicação do direito e contexto social. 2. ed. São Paulo: Revista dos Tribunais, 2000.

BEVILAQUA, Clovis. Código Civil dos Estados Unidos do Brasil. Rio de Janeiro: Ed. Rio, 1958.

BODNAR, João Henrique Pickcius Celant; RUDSON, Marcos (Org.). O Judiciário como instância de governança e sustentabilidade: descobertas, dúvidas e discordâncias. Florianópolis: 2018.

BÜLOW, Oskar Von. La Teoría de las Excepciones Procesales y los presupuestos procesales. Buenos Aires: Ediciones Jurídicas Europa-America, 1964.

CARNELUTTI, Francesco. Instituição de processo civil. Trad. Adrián Sotero De Witt Batista. Campinas: Servamda, 1999.

CASTRO FILHO, José Olimpio. Comentários ao Código de Processo Civil, v. X: arts. 1.103 a 1.220. 3 ed. Rio de Janeiro: Forense, 1983.

CHIOVENDA, Giuseppe. Instituiçôes de direito processual civil. Tradução de J. Guimarães Menegale. v. II. 2. ed. São Paulo: Saraiva, 1965.

CORRÊA, Fábio Peixinho Gomes. Governança Judicial. São Paulo: Quartier Latin, 2012.

DEVIS ECHANDIA, Hernando. Teoria general del proceso: aplicable a toda clase de procesos. Tomo I. Buenos Aires: Editorial Universidad, 1984.

DI PIETRO, Maria Sylvia Zanella. Direito Administrativo. 30. ed. rev., atual. e ampl. Rio de Janeiro: Forense, 2017.

DWORKIN, Ronald. Levando os Direitos a Sério. São Paulo: Martins Fontes, 2002.

FABRÍCIO, Adroaldo Furtado. Comentários ao Código de Processo Civil - lei no 5.869, de 11 de janeiro de 1973, vol. VIII, tomo III, arts. 890-945. Rio de Janeiro: Forense, 1984.

FAZZALARI, Elio. Instituiçôes de Direito Processual. Campinas: Bookseller, 2006.

FERRAZ JR., Tércio Sampaio. Função social da dogmática jurídica. São Paulo: Max Limonad, 1998.

FREITAS, Juarez. Direito Fundamental à Boa Administração Pública. 3. ed. São Paulo: Malheiros Editores Ltda. 2014.

GADAMER, Hans-Georg. Verdade e método: traços fundamentais de uma hermenêutica filosófica. Tradução de Flávio Paulo Meurer. 3. ed. Petrópolis: Vozes, 1999.

GOULART, Clovis de Souto. Formas e Sistema de Governo. Porto Alegre/Florianópolis: Sérgio Antonio Fabris Editor/CPGD-UFSC, 1995. 
GRECO, Leonardo. Jurisdição voluntária moderna. São Paulo: Dialética, 2003.

HEIDEGGER, Martin. Ontología: hermenéutica de la facticidad. Versión de Jaime Aspiunza. Madrid: Alianza Editorial, 1998.

HOMMERDING, Adalberto Narciso. Teoría de la legislación y Derecho como integridad. Curitiba: Juruá, 2012.

JOHANNPETER, Jorge Gerdau. Prefácio. In: NARDES, João Augusto Ribeiro. Governança Pública. 2. ed. Belo Horizonte: Forum, 2016.

LEAL, André Cordeiro. Instrumentalidade do Processo em Crise. Belo Horizonte: Mandamentos, Faculdade de Ciências Humanas, FUMEC, 2008.

LUHMANN, Niklas. Legitimação pelo procedimento. Tradução de Maria da Conceição CorteReal. Brasília: Universidade de Brasília, 1980.

MARQUES, José Frederico. Ensaio sôbre a jurisdição voluntária. 2. ed. São Paulo: Saraiva, 1959.

MEIRELLES, Hely Lopes. Direito administrativo brasileiro. 39. ed. São Paulo: Malheiros, 2011.

MELLO, Celso Antônio Bandeira. Curso de Direito Administrativo. 2. ed. São Paulo: Melhoramentos Ltda., 2007.

MICHELI, Gian Antonio. Curso de derecho procesal civil. v. I. Traducción de Santiago Sentís Melendo. Buenos Aires: Ediciones Jurídicas Europa-América, 1970.

MIRANDA, Jorge. Manual de direito constitucional. Tomo V. Actividade constitucional do Estado. 2. ed. Coimbra: Coimbra, 2000.

MIRANDA, Pontes de. Comentários ao Código de Processo Civil, tomo XVI: arts. 1.103 a 1.210. Rio de Janeiro: Forense, 1977.

MOTTA, Francisco José Borges. Levando o direito a sério: uma crítica hermenêutica ao protagonismo judicial. 2. ed. rev. e ampl. Porto Alegre: Livraria do Advogado, 2012.

NARDES, João Augusto Ribeiro. Governança Pública. 2 ed. Belo Horizonte: Forum, 2016.

NUNES, Dierle José Coelho. Processo Jurisdicional Democrático: Uma Análise Crítica das Reformas Processuais. Curitiba: Juruá, 2008.

PANSARELLI, Daniel. Para uma história da relação ética-política. Revista Múltiplas Leituras, São Paulo, v. 2, n. 2, p. 9-24, jul./dez. 2009.

PASOLD, Cesar Luiz. Metodologia da Pesquisa Jurídica. Teoria e Prática. 14.ed. rev. atual. e ampl. Florianópolis: Insular, 2013.

ROSENBERG, Leo. Tratado de derecho procesal civil. Tomo I. Traducción de Ângela Romera Vera. Buenos Aires: Ediciones Jurídicas Europa-America, 1955. 
SAGÜES, Néstor Pedro. La interpretación judicial de la Constitución. Buenos Aires: Depalma, 1998.

SARLET, Ingo Wolfang; FENSTERSEIFER, Tiago. Direito Constitucional Ambiental. Constituição. Direitos Fundamentais e Proteção do Ambiente. 5.ed. rev. atual. ampl. São Paulo: Revista dos Tribunais, 2017.

SCHÖNKE, Adolfo. Derecho procesal civil. Barcelona: Bosch, 1950.

SILVA, Clovis do Couto e. Comentários ao Código de Processo Civil. São Paulo: Ed. Revista dos Tribunais, 1977. vol. 11, t.1.

SILVA, Ovídio A. Baptista da. Curso de processo civil: processo de conhecimento. v. 1. 4. ed. rev. e atual. São Paulo: Revista dos Tribunais, 1998.

STEIN, Ernildo. Aproximaçôes sobre hermenêutica. Porto Alegre: Edipucrs, 1996.

STEIN, Ernildo. História e ideologia. 3. ed. Porto Alegre: Movimento, 1972.

STRECK, Lenio Luiz. Hermenêutica e princípios da interpretação constitucional. In: CANOTILHO, J.J. Gomes; SARLET, Ingo Wolfgang; STRECK, Lenio Luiz; MENDES, Gilmar Ferreira. Comentários à Constituição do Brasil. 2. ed. São Paulo: Saraiva Educação, 2018.

STRECK, Lenio Luiz. Hermenêutica jurídica e $(\mathrm{m})$ crise: uma exploração hermenêutica da construção do direito. 10. ed. rev., atual. e ampl. Porto Alegre: Livraria do Advogado, 2011.

STRECK, Lenio Luiz. Verdade e consenso: Constituição, hermenêutica e teorias discursivas. Rio de Janeiro: Lumen Juris, 2006.

STRECK, Lenio Luiz; DELFINO, Lúcio. Novo CPC e decisão por equidade: a canibalização do Direito. In: Revista Consultor Jurídico (CONJUR), 29 de dezembro de 2015, 7h49min. Disponível em: https://www.conjur.com.br/2015-dez-29/cpc-decisao-equidade-canabalizacaodireito

TESHEINER, José Maria Rosa. Jurisdição voluntária. Rio de Janeiro: Aide Ed., 1992.

THEODORO JÚNIOR, Humberto. Curso de Direito Processual Civil. 52. ed. Rio de Janeiro: Forense: 2018. II v.

VARELA, Antunes, BEZERRA, J. Miguel, NORA, Sampaio e. Manual de processo civil. 2. ed. rev., e actual. de acordo com o dec-lei 242/85. Coimbra: Coimbra, 1985.

VATTIMO, Gianni. Introdução a Heidegger. 10. ed. Lisboa: Piaget, 1996.

VÉSCOVI, Enrique. Elementos para uma teoría general del proceso civil latinoamericano. México: UNAM, 1978.

VÉSCOVI, Enrique. Teoría general del proceso. Bogotá: Temis, 1984. 